\title{
On groundwater fluctuations, evapotranspiration, and understory removal in riparian corridors
}

\author{
Maceo C. Martinet, ${ }^{1}$ Enrique R. Vivoni, ${ }^{2}$ James R. Cleverly, ${ }^{1}$ James R. Thibault, ${ }^{1}$ \\ Jennifer F. Schuetz, ${ }^{1}$ and Clifford N. Dahm ${ }^{1}$ \\ Received 9 May 2008; revised 5 December 2008; accepted 24 February 2009; published 28 May 2009.
}

[1] This study utilizes 7 years of continuously monitored groundwater-level data from four sites along the Río Grande riparian corridor in central New Mexico to calculate evapotranspiration from groundwater and assess impacts of understory vegetation removal during a restoration project. Diurnal groundwater fluctuation measurements were used to compare the well-known White method for estimating evapotranspiration from groundwater $\left(E T_{g}\right)$ to colocated measurements of total riparian evapotranspiration $(E T)$ measured using the eddy covariance method. On average, the two methods were linearly correlated and had similar variability, but groundwater hydrograph estimates of $E T_{g}$ tended to be larger than tower $E T$ estimates. Average $E T_{g}$ estimates for two wells at one site ranged from $91.45 \%$ to $164.77 \%$ of measured tower ET estimates, but were also shown to range from $57.35 \%$ to $254.34 \%$ at another site. Comparisons between the methods improved with deeper water tables, reduced groundwater and river connectivity, and where soil profiles were dominated by coarse-sized particles. Using a range of texturebased estimates of specific yield $\left(S_{y}\right)$ with water table position improves the field application of the White method. River-induced fluctuations in groundwater increased the variability of $E T_{g}$ measurements. Removal of understory vegetation at one site resulted in a small but significant reduction in diel groundwater fluctuation amplitude of $19-21 \%$. Caution is required when understory vegetation removal is used as a means to decrease overall riparian ET. Diel groundwater fluctuation amplitudes can be useful in gauging the hydrological effects of vegetation removal. Riparian groundwater hydrographs are critical to investigating the hydrologic connectivity between river and shallow groundwater, the temporal patterns of vegetative consumption, and monitoring changes to the vegetation community.

Citation: Martinet, M. C., E. R. Vivoni, J. R. Cleverly, J. R. Thibault, J. F. Schuetz, and C. N. Dahm (2009), On groundwater fluctuations, evapotranspiration, and understory removal in riparian corridors, Water Resour. Res., 45, W05425, doi:10.1029/2008WR007152.

\section{Introduction}

[2] Groundwater hydrographs can provide insights into the ecohydrological processes occurring in riparian ecosystems. The spatial and temporal dynamics of groundwaterlevel position have been shown to control vegetation composition and nutrient processing in riparian corridors [Burt et al., 2002; Hefting et al., 2004; Leyer, 2005]. Groundwater wells within floodplain areas can provide information regarding ecosystem hydrological and biogeochemical processes [Peterjohn and Correll, 1984; Smith et al., 1991; Brunke and Gonser, 1997; Morrice et al., 1997; Sjodin et al., 2001; Schilling et al., 2004, 2006; Davis et al., 2007].

\footnotetext{
${ }^{1}$ Department of Biology, University of New Mexico, Albuquerque, New Mexico, USA.

${ }^{2}$ Department of Earth and Environmental Science, New Mexico Institute of Mining and Technology, Socorro, New Mexico, USA.

Copyright 2009 by the American Geophysical Union. 0043-1397/09/2008WR007152\$09.00
}

[3] Deployment of monitoring wells along groundwater gradients is an effective means to assess hydrological controls on the processing of nutrient fluxes in riparian ecosystems [Lowrance et al., 1997; Hedin et al., 1998; Clément et al., 2003; Butturini et al., 2003; Vellidis et al., 2003; Wigington et al., 2003; Dhondt et al., 2006]. Furthermore, analysis of groundwater and surface water hydrographs can be used to estimate aquifer hydraulic properties, which influence riparian ecosystem processing [Ferris, 1951; Smith, 1999; Jha et al., 2004; Jung et al., 2004; Woessner, 2000; Vivoni et al., 2006]. While wells in riparian areas have allowed improved understanding of hydrological and biogeochemical processes, there is still a need to further explore groundwater observations as ecosystem research tools. One important area of investigation is the use of well hydrographs to assess the interaction of riparian vegetation dynamics and water table fluctuations.

[4] Riparian evapotranspiration (ET), which combines transpiration from overstory and understory plants and evaporation from soil surfaces and open water, is a critical ecohydrological flux which can be used to assess impacts of vegetation on surface and groundwater resources [Newman 
et al., 2006; Cleverly et al., 2006a; Zhang and Schilling, 2006; Rodríguez-Iturbe et al., 2007]. Several studies have analyzed groundwater well hydrographs in an attempt to estimate water consumption from phreatophytic vegetation whose roots directly access groundwater [e.g., White, 1932; Troxell, 1936; Meyboom, 1964; Gerla, 1992; Loheide et al., 2005; Butler et al., 2007; Lautz, 2008; Loheide, 2008]. Direct consumption of groundwater by phreatophytes $\left(E T_{g}\right)$ represents an explicit link between ecosystem processes and subsurface hydrological dynamics. Evidence for groundwater evapotranspiration has been frequently observed in the diurnal fluctuations of shallow water tables in vegetated riparian zones [e.g., Dahm et al., 2002; Healy and Cook, 2002; Schilling et al., 2006; Steinwand et al., 2006; Zhang and Schilling, 2006; Butler et al., 2007, Gribovszki et al., 2008]. Groundwater hydrographs in riparian corridors exhibit distinct diurnal patterns during the summer growing season corresponding to phreatophyte transpiration. Vegetation-induced groundwater fluctuations are characterized by an oscillating pattern of a high water table during the early morning and a low water table during the late afternoon. Seasonal variations in $E T_{g}$-induced fluctuations may serve as a tool for tracking vegetation consumption patterns as well as the effects of vegetation removal on riparian evapotranspiration.

[5] Estimating vegetation consumption of groundwater using well hydrograph records was proposed by White [1932] and has been used widely in different riparian settings [e.g., Troxell, 1936; Farrington et al., 1990; Gerla, 1992; Rosenberry and Winter, 1997; Loheide et al., 2005; Butler et al., 2007; Lautz, 2008; Loheide, 2008]. The White method provides estimates of groundwater transpiration $\left(E T_{g}\right)$ based on the analysis of diurnal water table fluctuations and an estimate of the specific yield near the water table position. A principal assumption of the White method (described in detail in section 3 ) is that diurnal fluctuations of an unconfined water table are a direct response of the diurnal pattern of phreatophyte transpiration, and not a response to groundwater temperature, atmospheric pressure, or local pumping, or to changes to boundary conditions such as a nearby river or water body. In addition, the method applies to circumstances where the dominant source of water used by riparian vegetation is groundwater and not vadose zone water. Butler et al. [2007] argue that measurements of riparian evapotranspiration (ET) should only be attempted when the evapotranspirative consumption of groundwater $\left(E T_{g}\right)$ is a dominant term, as neither soil nor open water evaporation are considered in the White method.

[6] One practical advantage of the White method is that the technique can be applied to a set of inexpensive wells deployed in a riparian corridor to understand variations in $E T_{g}$ and the groundwater response to vegetation changes. Recent studies have evaluated the White method to improve its application in field settings and provide guidelines for parameter estimation [Loheide et al., 2005; Butler et al., 2007]. Loheide et al. [2005] used numerical modeling to explore the effects of drainage time, depth to water table, specific yield, and flow geometry on $E T_{g}$ estimates using the White method. The study showed that for depths to groundwater exceeding $1 \mathrm{~m}$ and sediments with $>10 \%$ fine particles, a reasonable estimate of specific yield can be obtained using sediment texture. Butler et al. [2007] showed that the major controls on phreatophyte-induced groundwater fluctuations depend on weather conditions, plant density, and species type, as well as on the specific yield of the sediments near the water table. These advances motivated our study by providing techniques to appropriately use the White method in riparian corridors.

[7] Our study is focused primarily on comparing the White method estimates of $E T_{g}$ with measurements of riparian evapotranspiration $(E T)$ in different plant communities found within a vegetated riparian corridor of a large, semiarid river system. Several methods are available to estimate total ET along riparian corridors, with the threedimensional sonic eddy covariance (3SEC) method being a popular technique [e.g., Shafroth et al., 2005; Nagler et al., 2005; Cleverly et al., 2002, 2006a]. The 3SEC method (described in detail in section 3 ) requires the deployment of expensive meteorological equipment and careful site placement [cf. Cleverly et al., 2006a]. Because of its inexpensive nature, the White method is an appealing alternative that requires analysis of only well hydrographs and aquifer properties near the water table position. To our knowledge, however, comparisons of the White and 3SEC methods have not been carried out in vegetated riparian corridors. Direct comparison of these techniques at colocated sites is important for evaluating the usefulness of the White method in riparian corridors where groundwater transpiration is a major ET component. Long-term comparisons in a range of riparian communities would also allow use of groundwater wells to estimate ET in areas lacking meteorological data or where tower deployment is not feasible.

[8] Groundwater hydrographs also provide insights into the impact of riparian vegetation removal on aquifer processes, as well as insights on how water table fluctuations may affect ecosystem restoration efforts [e.g., Qashu and Evans, 1967; Matheussen et al., 2000; Tabacchi et al., 2000; Swank et al., 2001; Biggs et al., 2004; Cooper et al., 2006; Neill et al., 2006; Newman et al., 2006; Scott et al., 2005]. Removal of phreatophyte plants is increasingly used as a means to reduce consumptive water demand in riparian corridors [Parker et al., 2005; Newman et al., 2006; Wilcox et al., 2006]. Nevertheless, few studies have assessed the effectiveness of restoration projects in riparian ecosystems [Shah et al., 2007]. This is particularly important in arid and semiarid regions where removal of invasive phreatophytes is considered an effective management technique [Swank et al., 2001; Shafroth et al., 2005; Cooper et $a l ., 2006]$. Analysis of groundwater hydrographs before and after a restoration project can potentially provide an estimate of the aquifer response to the vegetation change. To achieve this, long-term groundwater measurements are needed in a riparian restoration zone, along with estimates of plant biomass or leaf area index to track vegetation removal and recovery, if any.

[9] In this study, we utilize long-term groundwater hydrographs at four instrumented sites along a vegetated riparian corridor in the Río Grande floodplain to achieve two major objectives. First, we compare the White and 3SEC methods for estimating riparian evapotranspiration and its groundwater component using 7 years of meteorological flux and groundwater data. To our knowledge, this is the first extensive comparison between these two methods using long-term field data. Second, we use groundwater data that 
were collected before and after an understory removal project to evaluate its impact on the groundwater resource. We hypothesize that estimates of daily evapotranspiration from the White method are similar to estimates from the 3SEC method, and that plant-induced diurnal fluctuations in the groundwater can successfully track vegetation removal.

\section{Study Sites and Instrumentation}

[10] Four long-term research sites (Albuquerque, Belen, Sevilleta, Bosque del Apache) were established in the middle Río Grande riparian corridor to measure evapotranspiration, biodiversity, and the temporal dynamics of groundwater level (Figure 1) [e.g., Molles et al., 1998; Dahm et al., 2002; Cleverly et al., 2002; Cleverly et al., 2006a]. As Figure 1 illustrates, the middle Río Grande flows from Otowi Bridge to Elephant Butte Reservoir in central New Mexico.

[11] Each site has a distinct vegetation composition. Albuquerque (ALB) and Belen (BLN) are dominated by native cottonwoods (Populous deltoids spp. wislizeni) with densities of 122 and 278 trees $^{-1}$, respectively [Cleverly et al., 2006a, 2006b]. Understory vegetation at the ALB site was a dense thicket of salt cedar (Tamarix chinensis) and Russian olive (Elaeagnus angustifolia) that was removed in late 2003 and early 2004 during a riparian restoration project. The understory vegetation at the BLN site is mostly native shrubs. Conversely, Sevilleta (SEV) and Bosque del Apache (BDA) sites are dominated by invasive salt cedar communities. SEV also has a mixture of various native halophytes such as mesquite (Prosopsis pubescens) and saltbush (Atriplex L. spp), while BDA is a dense, monospecific salt cedar stand. The four sites are representative of the middle Río Grande riparian ecosystem, which currently occupies land in the river floodplain.

[12] Climate in the region is classified as semiarid with an annual precipitation ranging from 20 to $31 \mathrm{~cm}$, with approximately $50 \%$ occurring during the summer monsoon period (July-September) [e.g., Milne et al., 2003; Weiss et al., 2004]. Hydrological conditions differ at each site based upon the proximity to the river and its seasonal flooding during spring snowmelt and the North American monsoon [e.g., Dahm et al., 2002; Vivoni et al., 2006]. To assess flood conditions, we gathered river stage and discharge data from the closest U.S. Geological Survey (USGS) stream gauges near the four riparian sites at 30-min intervals (Figure 1b). BLN and BDA are flood-prone sites with recurrence intervals of $\sim 3$ years, while ALB and SEV are considered nonflooding sites as significant inundation has not occurred since 1942 [Molles et al., 1998]. Flood-prone sites reflect a high degree of surface water connection between the Río Grande and its floodplain. Differing hydrologic conditions at these sites have allowed monitoring long-term effects of flooding on riparian biodiversity and ecological processes [Ellis et al., 1993; Crawford et al., 1996; Molles et al., $1998]$.

[13] To monitor subsurface hydrologic conditions, each riparian site has a network of five shallow groundwater wells installed across the water table, with an average depth of $3.5 \mathrm{~m}$ below the surface. Groundwater wells consist of a $5.0 \mathrm{~cm}$ ID polyvinyl chloride (PVC) tubing with a screened lower section $(0.25 \mathrm{~mm}$ screen slot size). Figure 1 presents the arrangement of the five wells at each site, with the center well located next to the meteorological flux tower and the other four wells at $40 \mathrm{~m}$ distance in each cardinal direction. Depth to groundwater was measured every $30 \mathrm{~min}$ at three of the five wells using automated pressure transducers (EEI, Las Cruces, New Mexico, and Solinst Canada Ltd., Georgetown, Ontario). Instrumentation sites at the ALB, BLN, SEV, and BDA locations are placed approximately at $123,122,806$, and $268 \mathrm{~m}$, respectively, from the Río Grande bank, as measured from the center well (Figure 1).

[14] Meteorological flux tower instrumentation at each site was placed between 2 and $2.5 \mathrm{~m}$ above the vegetation canopies, which are $\sim 25 \mathrm{~m}$ tall for cottonwood stands (ABQ and BLN) and $\sim 10 \mathrm{~m}$ tall for the salt cedar sites (SEV and BDA). The eddy covariance (3SEC) technique is the benchmark method for measuring turbulent fluxes over tall vegetation and under the advective conditions experienced in riparian corridors [e.g., Drexler et al., 2004]. Core flux instrumentation includes a high-frequency $(10 \mathrm{~Hz}$ sampling with a 30-min integration period) sonic anemometer (CSAT3) to measure three-dimensional wind velocity fluctuations, a krypton hygrometer (KH20) or open-path infrared gas analyzer (IRGA) to measure fluctuations in humidity, and a thermocouple to measure air temperature fluctuations (see Dahm et al. [2002] and Cleverly et al. [2002, 2006a] for details). Since a simplified energy balance $\left(R_{n}-G=H+\lambda E T\right)$ can be tested using the eddy covariance technique, measurements were also made of the net radiation $\left(R_{n}\right)$ and ground heat flux $(G)$ at each site to complement the sensible $(H)$ and latent $(\lambda E T)$ heat flux estimates. The latent heat flux $(\lambda E T)$ represents conditions in a time-variable footprint upwind of the meteorological tower that depends on the horizontal wind speed and direction [e.g., Cooper et al., 2003; Drexler et al., 2004]. Supporting instruments were also deployed at each site to measure surface soil moisture and soil temperature as well as precipitation and atmospheric pressure.

[15] In 2003, the nonnative understory vegetation at the ALB site was removed using mechanical masticators and direct herbicide application. The removed wood was primarily chipped and spread over the ground. To track changes induced by the restoration project, the leaf area index (LAI), defined as the projected area of the leaves per unit ground area, was measured using an LAI2000 (Li-Cor, Lincoln, Nebraska). Measurements were made each June at the ALB site during the 3 years prior to 2000-2002, during 2003 , and the third year after complete vegetation removal (2006). LAI measurements were collected near each of the five wells under the canopy and in the open sky on the nearby road. The year following vegetation removal (2004) showed a $9 \%$ decrease in annual $E T$, as measured by the 3SEC method, compared with an increase of $12 \%$ at all other sites [Cleverly et al., 2006b]. However, if the nonnative understory is allowed to regrow, then the decreases in annual ET have been hypothesized to be short-lived [Shafroth et al., 2005; Cleverly et al., 2006b].

\section{Evapotranspiration Estimation Methods}

[16] In this study, we compare the daily riparian evapotranspiration (ET in $\mathrm{mm} \mathrm{d}^{-1}$ ) obtained using the 3SEC method to the daily groundwater evapotranspiration $\left(E T_{g}\right.$ in $\mathrm{mm} \mathrm{d}^{-1}$ ) from the White method. Currently, the 3SEC technique is the most direct method for measuring ET as a 

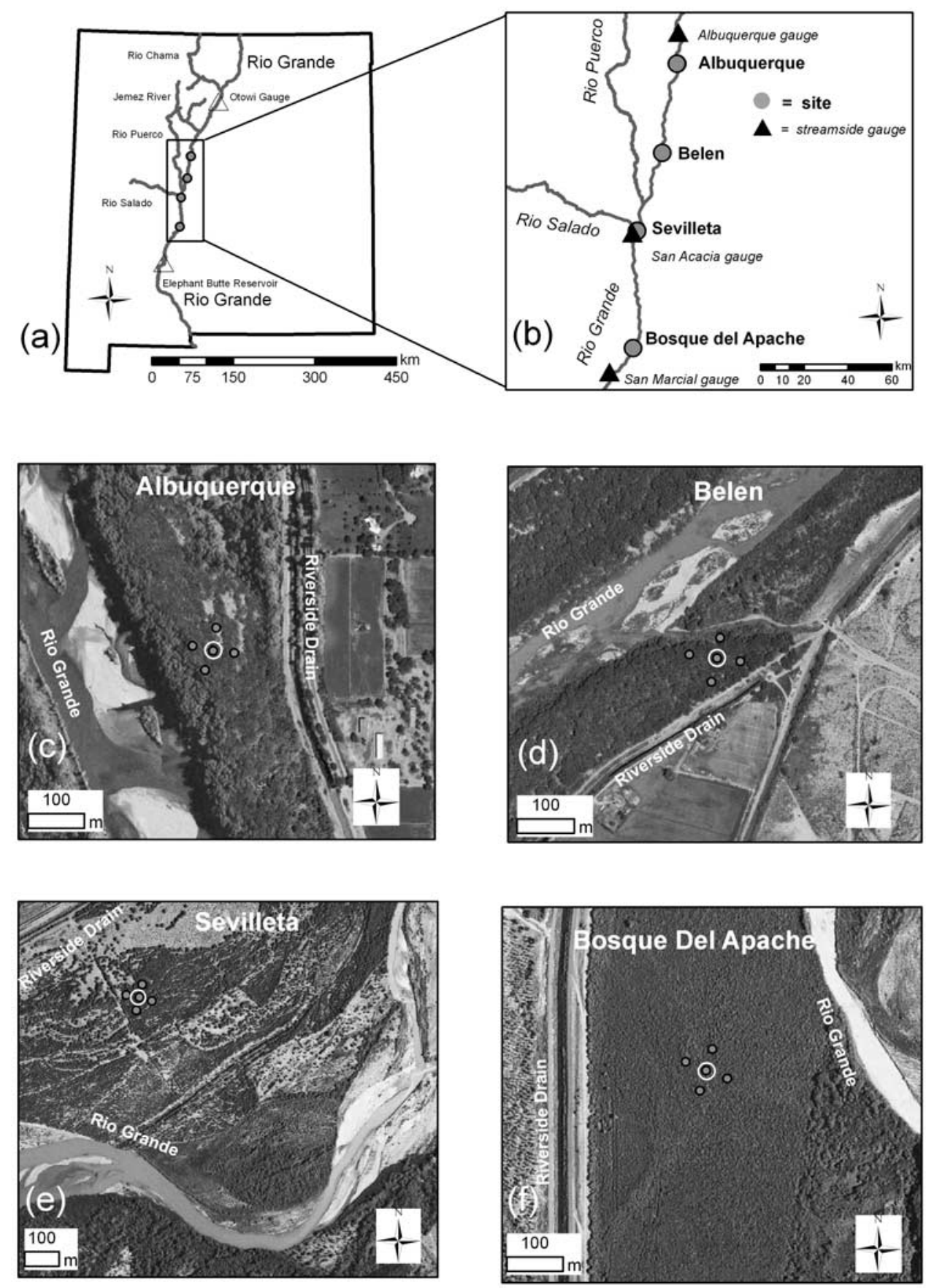

Figure 1. (a) Location of the study sites in New Mexico with the major tributaries to the Río Grande. Circles are locations of the study sites. Triangles are the U.S. Geological Survey (USGS) Otowi streamflow gauge and Elephant Butte Reservoir that delimit the northern and southern extents of the Middle Río Grande. (b) Close-up of the four sites (circles) with location of USGS stream gauges (triangles), Albuquerque (08330000), San Acacia (08354900), and San Marcial (08358400). Gray color composite orthophotos (1 m resolution) of study sites show location of monitoring wells, river, drainage canals, and other riparian features at (c) Albuquerque (ALB), (d) Belen (BLN), (e) Sevilleta (SEV), and (f) Bosque del Apache (BDA). Circles are the locations of the five shallow groundwater monitoring wells. Center well is outlined with a circle in proximity to the meteorological flux tower.

specific function of covariance between turbulent fluctuations in vertical wind velocity $\left(w^{\prime}\right)$ and specific humidity $\left(q^{\prime}\right)$. Along riparian forests in the Río Grande, the footprint can range from 40 to $60 \mathrm{~m}$ around the salt cedar sites and up to $200 \mathrm{~m}$ around the cottonwood-dominated sites [see Cleverly et al., 2006a]. Various standard corrections are applied to account for limitations of the 3SEC technique, as detailed by Cleverly et al. [2006a]. Closure of the energy balance has been ensured by utilizing the Bowen ratio $(H / \lambda E T)$ to force thermodynamic equilibrium [see Cleverly et al., 2002, 2006a]. 


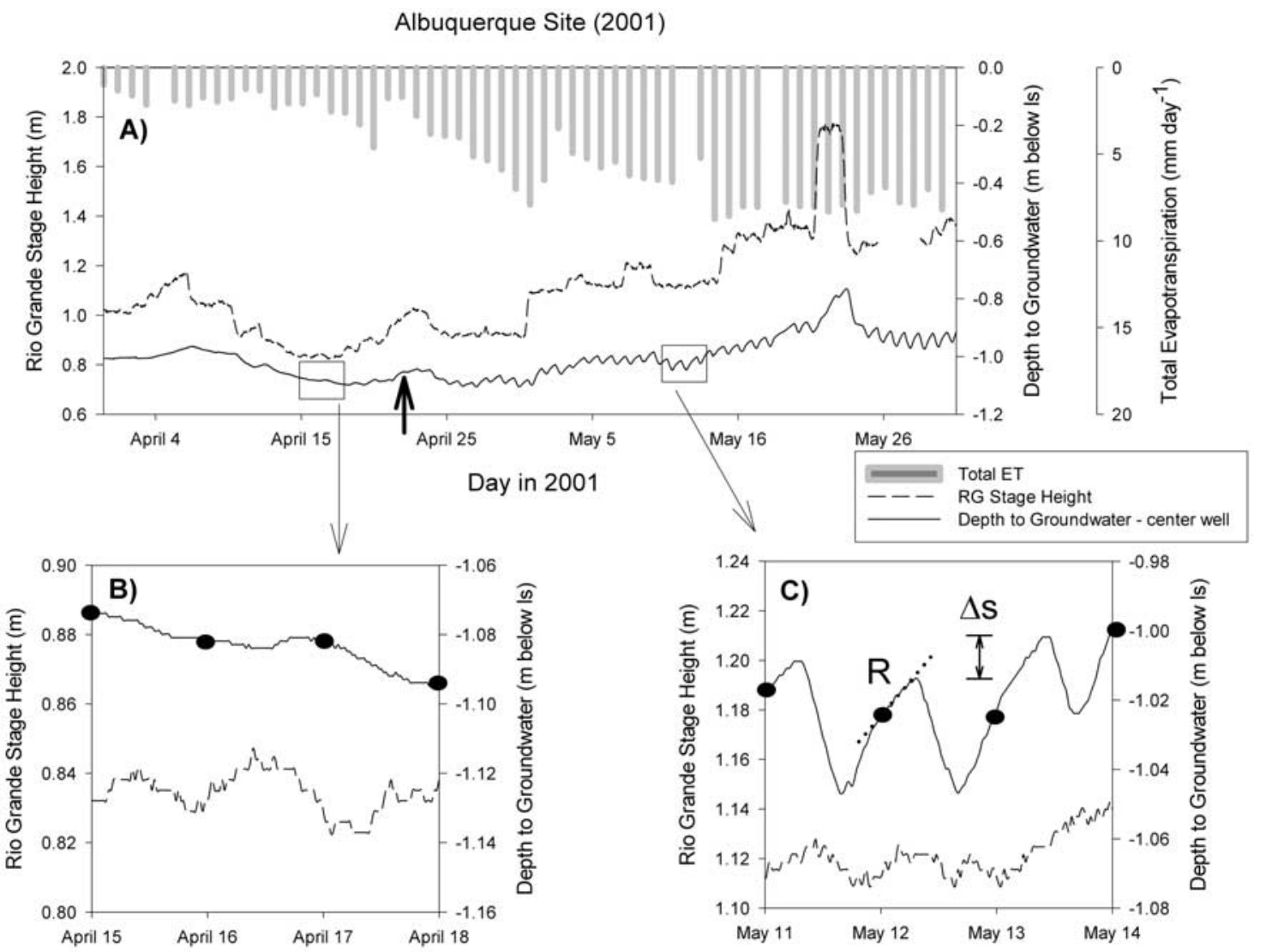

Figure 2. (a) Río Grande stage height, depth to groundwater, and total evapotranspiration at center well at the ALB site, 1 April to 31 May 2001. The arrow marks the beginning of the diurnal oscillations in water table. (b and c) Three-day intervals of river stage and depth to groundwater prior to and after the fluctuations commence. Dots mark midnight. Note how the diurnal groundwater oscillations cannot be explained by the river stage fluctuations. Minimum depth to groundwater typically occurs before the Sun rises, corresponding to the period of day during which photosynthesis is negligible and little groundwater consumption occurs. Maximum depth to water table typically occurs in the late afternoon, corresponding to high photosynthetic activity. $R$ and $\Delta s$ are variables used in the White method and estimated from the groundwater observations.

[17] Daily $E T_{g}$ estimates using the White method are based on diurnal fluctuations in water table [White, 1932; Loheide et al., 2005; Butler et al., 2007]. As a result, the method only accounts for one component of the total riparian evapotranspiration $(E T)$, generally defined as,

$$
E T=E T_{g}+E_{o}+E_{i}+E T_{s}
$$

where $E_{o}$ and $E_{i}$ are evaporation from open water and intercepted canopy water, and $E T_{S}$ is evapotranspiration from the unsaturated soil. The groundwater phreatophyte transpiration component is estimated using the White method as (see Figure 2c)

$$
E T_{g}=S_{y}(\Delta s / t+R)
$$

where $E T_{g}$ is the rate of evapotranspirative consumption of groundwater averaged over a $24-\mathrm{h}$ period $\left(\mathrm{mm} \mathrm{d}^{-1}\right), S_{y}$ is the specific yield (dimensionless), $\Delta s$ is the daily change in aquifer storage $(\mathrm{mm}), R$ is the net inflow (recovery) rate $\left(\mathrm{mm} \mathrm{d}^{-1}\right)$, and $t$ is the time period of 1 day. The daily storage change $(\Delta s)$ is computed from the difference in the maximum water table elevations of two consecutive days. A positive $\Delta s$ value indicates the water table is falling over a 24-h period and a negative value indicates a rising water table. The net inflow or recovery rate $(R)$ is calculated as the rate of change (e.g., slope) in the water table elevation in a period with negligible transpiration, typically assumed between midnight and 0400 LT [Loheide et al., 2005; Butler et al., 2007].

[18] Figure 2 illustrates the seasonal differences in diurnal fluctuations in water table observed during the transition from spring to summer seasons in the Río Grande riparian corridor, and the application of the White method. While these data are specifically from the ALB site for the year 2001, similar patterns are observed for other years in the record and at the other riparian sites. Note that the depth to groundwater $(\mathrm{m})$ from the center well (closest to the 3SEC tower) begins to show diurnal fluctuations around 22 April 2001 (arrow). The water table elevation at this site generally follows trends in the river stage as measured at a nearby USGS gauging station. Daily oscillations in river stage are minimal and show little in common with the seasonal differences in groundwater fluctuations that are characteris- 
tic of riparian transpiration. Although river stage fluctuations are minimal, it is unclear whether the periodicity in river stage corresponds to a diurnal pattern of thermal expansion and contraction or is an equipment-induced artifact. Onset of the diel groundwater oscillations is coincident with an increase in the daily riparian evapotranspiration measured by the 3 SEC method at the site (increasing from $\sim 2$ to $\sim 7 \mathrm{~mm} \mathrm{~d}^{-1}$ during 22-30 April). To further illustrate the changes in groundwater response during the transition into the growing season, Figures $2 b$ and $2 c$ present river stage and groundwater elevations for two 3-day periods in the record (15-18 April and 11-14 May). Note that diurnal fluctuations are absent in the early period, while transpiration from the cottonwood overstory and nonnative understory at the site induces oscillations in the water table elevation for the later period.

[19] To accurately calculate $E T_{g}$ using the White method, we removed periods of groundwater fluctuations that were induced by rapid changes in river stage. This issue has not been previously addressed since most prior studies focus on nonflowing channels or short-term periods of steady channel flow [Loheide et al., 2005; Steinwand et al., 2006; Butler et al., 2007]. In addition, daily $E T_{g}$ data were inspected for consistency by removing any negative $E T_{g}$ values resulting from spurious water table fluctuations. Furthermore, short-term $E T_{g}$ values exceeding twice the standard deviation above the annual mean $E T_{g}$ were filtered from the record. Taken together, these three processing steps ensured the removal of $E T_{g}$ outliers that corresponded to water table fluctuations during river pulses. Prior to calculating $E T_{g}$, pressure transducer data were filtered for spikes and noise. The data also were frequently calibrated in the field with manual measurements of depth to groundwater. Precipitation events during this study were not shown to affect groundwater dynamics directly due to soil infiltration. Precipitation events only affected groundwater dynamics through precipitation-induced river pulses, which we accounted for in our data processing procedures. This data processing was essential to ensure a consistent set of $E T_{g}$ values across all sites and years.

[20] The only variable in the White method not estimated directly from groundwater fluctuations is the specific yield $\left(S_{y}\right)$, defined as the water volume released from storage per unit drop in the water table height per unit land area. $S_{y}$ is a property of depth to water table, antecedent moisture conditions, duration of drainage, and the sediment texture [e.g., Hornberger et al., 1998; Healy and Cook, 2002]. Estimating $S_{y}$ in a field setting is challenging due to heterogeneities in aquifer properties that interact with a fluctuating water table. Recent papers have explored techniques to estimate specific yield by characterizing the soil horizon properties near the water table [Loheide et al., 2005; Butler et al., 2007]. Using a numerical simulation, Loheide et al. [2005] showed that the specific yield of a substrate with high porosity decreases as the percent of fines increases and is a function of depth to groundwater. The authors propose a method to estimate the readily available specific yield using sediment texture [see Loheide et al., 2005, Figure 10] that we adopt in this study. Given the uncertainties inherent in this technique, we account for possible variations in $S_{y}$ for each soil texture (details provided in section 4.2 ). Soil texture analyses (\% clay, sand, silt) were performed on samples taken during installation of two of the five wells at each site using the hydrometer method [Birkeland, 1984]. At each site, soil analysis was performed on the first $10 \mathrm{~cm}$, with subsequent analysis performed when there was a visible difference in soil type. We estimated the readily available specific yield at each well using the soil properties at depths over which the water table was observed to occur during the long-term monitoring effort (2000-2006).

\section{Results}

\subsection{Surface Water and Groundwater Hydrographs}

[21] Peak river flows in the Río Grande typically occur during the snowmelt (April-May) and monsoon (JulySeptember) periods (Figure 3). River stage height is used here to describe river flows instead of discharge because stage height represents the hydraulic head in the river channel and can be directly related to groundwater elevations. The timing and magnitude of the peak flows varied annually during the period of this study (2000-2006). As shown in Figure 3, annual maximum flows at the ALB stream gauge occurring in 2000, 2002, and 2003 were significantly reduced as compared with 2001, 2004, 2005, and 2006. For convenience in our study, sampling years with lower snowmelt and monsoon flood pulses are labeled as dry years $(2000,2002,2003)$, while the remaining years are considered wet $(2001,2004,2005,2006)$. The only wet year lacking snowmelt-derived peak flow was 2006, in which spring streamflow was significantly muted due to the relatively dry winter, while intense monsoon rainfall led to large summer flows [Gutiérrez-Jurado et al., 2007]. River stage data at the three gauging stations (see Figure 1b) revealed spatial heterogeneity in how this river reach responded to wet and dry years (Figure 3). Downstream river response varies due to hydrologic inputs from the Río Salado and Río Puerco tributaries (Figure 1) as well as losses to the shallow aquifer [Vivoni et al., 2006] and irrigation diversion dams.

[22] The hydrologic connectivity between the river and shallow groundwater varies for each of the study sites (data shown only for ALB and SEV). At the daily timescale, groundwater at three sites, ALB, BLN, and BDA, is highly responsive to changes in river stage, responding on average about $14-24 \mathrm{~h}, 24-34 \mathrm{~h}$, and 4-8 $\mathrm{h}$ after the change in river stage, respectively (not shown). On the other hand, groundwater at the SEV site is comparatively unresponsive to immediate changes to the river stage (Figures $3 \mathrm{~d}$ and $3 \mathrm{e}$ ) with a longer 3- to 4-day delay. Although groundwater at the SEV site does not respond rapidly to changes in the river stage, it does follow the annual runoff cycles within the Río Grande (i.e., annual groundwater oscillations clearly shown in Figure 3e). As in other sites, the water table rises during the snowmelt runoff period and decreases steadily during interstorm periods prior to monsoon activity. Groundwater at both ALB and SEV sites exhibit short-term responses to large individual flow events as shown in 2006. During that year, both ALB and SEV sites responded slowly to low snowmelt runoff but demonstrated a dramatic increase in water table position due to the high monsoon rainfall and runoff [e.g., Gutiérrez-Jurado et al., 2007]. 
Albuquerque
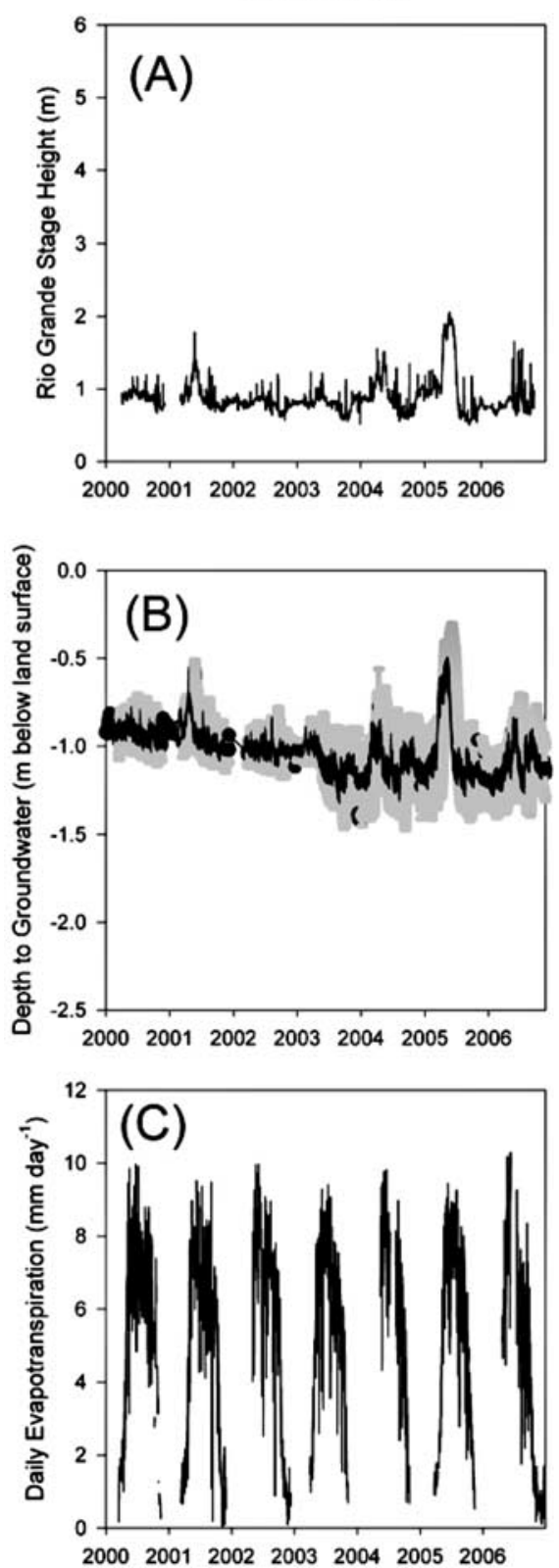

Sevilleta
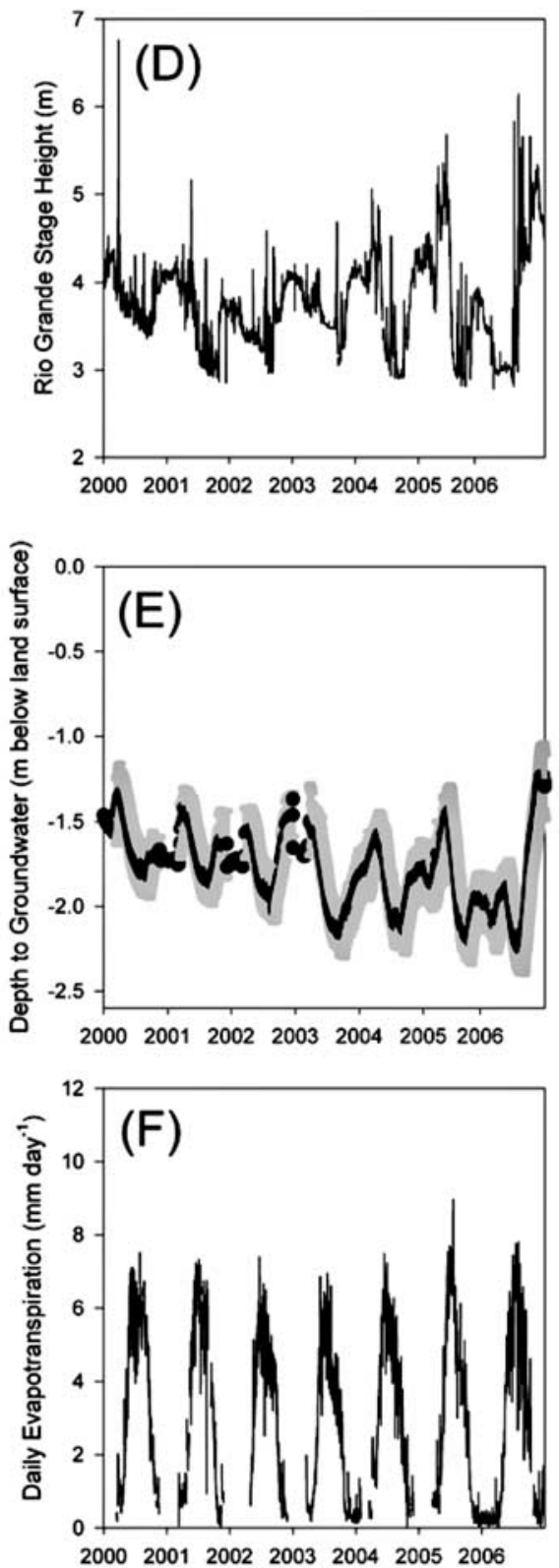

Figure 3. Río Grande stage height (m), average depth to groundwater ( $\mathrm{m}$ below land surface), and daily evapotranspiration $\left(\mathrm{mm} \mathrm{d}^{-1}\right)$ during the 2000-2006 period for (a-c) ALB site and (d-f) SEV site. The depth to groundwater is averaged (solid curve) over the four wells at the site. The shaded area represents the range ( \pm 1 standard deviation) in the four wells. Note that the depths to groundwater are given in negative values where the land surface is $z=0$. Daily evapotranspiration $(E T)$ data $\left(\mathrm{mm} \mathrm{d}^{-1}\right)$ are derived from the meteorological towers using the three-dimensional sonic eddy covariance (3SEC) method. Blank regions indicate that no data are available. Year begins at the hatch mark.

[23] The shallowest depth to groundwater occurred at the two flooding sites, BLN and BDA, which exhibited ponded water on the land surface during some periods in wet years. The annual depth to water table at these sites, averaged across the study period and using all wells on site, was 0.78 and $0.75 \mathrm{~m}$, respectively, below the land surface. Deeper groundwater occurred at the nonflooding sites, ALB and SEV, with annual averaged depths of 1.03 and $1.78 \mathrm{~m}$ below the surface. Interestingly, dry and wet years did not result in significant difference in the averaged depth to groundwater at each of the four sites. Nevertheless, the occurrence of wet or dry years did affect the pattern of groundwater fluctuations. Specifically, the average daily ranges of the water table position were reduced during the dry years as compared with the wet years. This finding was only statistically significant $(\mathrm{P}<0.06)$ at the two flooded sites.

\subsection{Using Groundwater Well Hydrographs} to Estimate $\boldsymbol{E} \boldsymbol{T}_{g}$

\subsubsection{Specific Yield Estimates}

[24] Figure 4 presents the soil texture estimates (\% sand, $\%$ silt, $\%$ clay) at the available wells in each study site for 

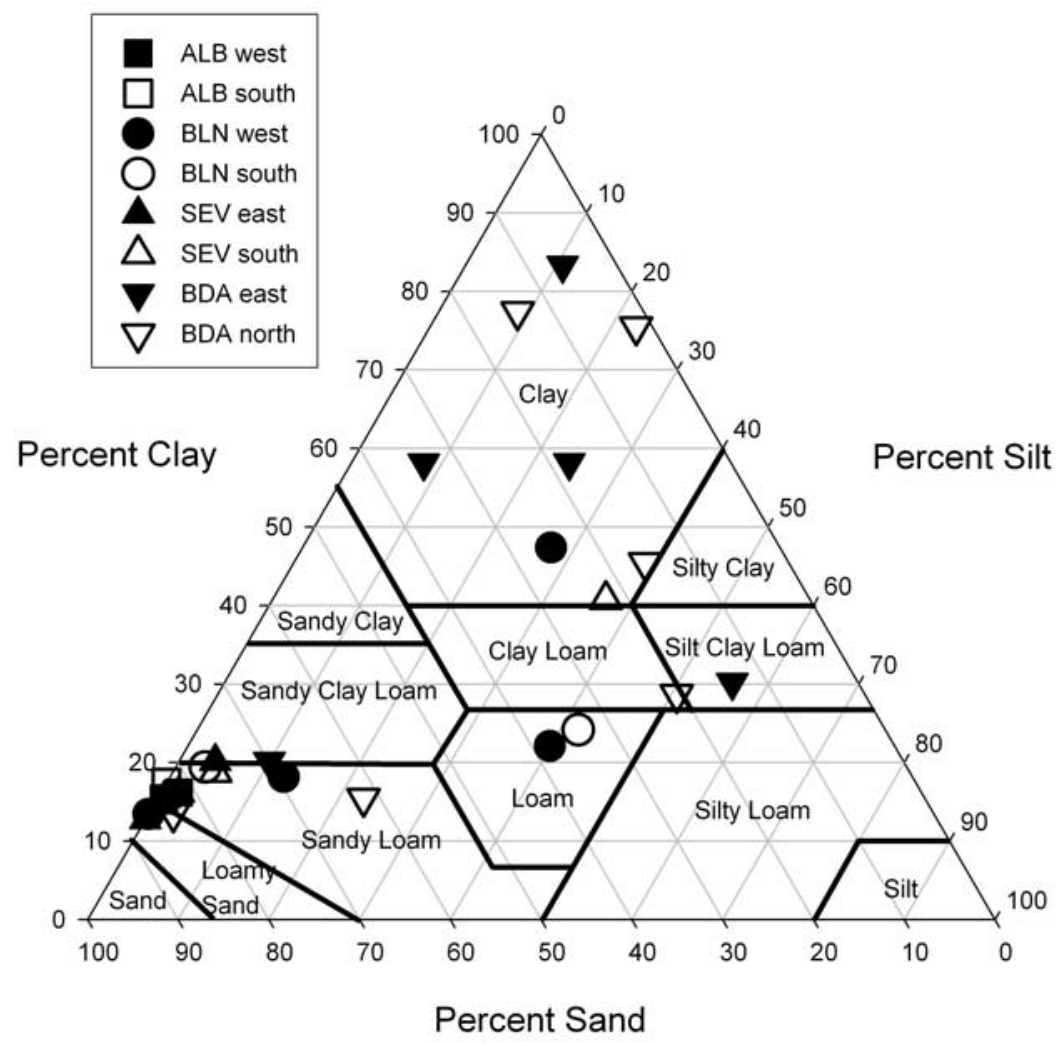

Figure 4. Soil texture classification (\% silt, \% clay, \% sand) of sediments within the zone of groundwater fluctuations at all four sites. Solid and open symbols for ALB and BLN sites correspond to west and south wells. Solid symbols for SEV and BDA sites are east wells, while open symbols are south and north wells, respectively.

the groundwater fluctuation intervals. For each soil classification, we used the high and low estimates of the readily available specific yield values given by Loheide et al. [2005, Figure 10]. Because of the uncertainties inherent in the $S_{y}$ estimates, a range of values for each soil texture classification was considered more appropriate than a single value of $S_{y}$. As a result, $E T_{g}$ estimates from the White method at each well in our study represent a range that corresponds to high and low $S_{y}$ estimates for each soil classification.

[25] Sediment profiles at the ALB site revealed sandy loam texture at both the west and south wells across the

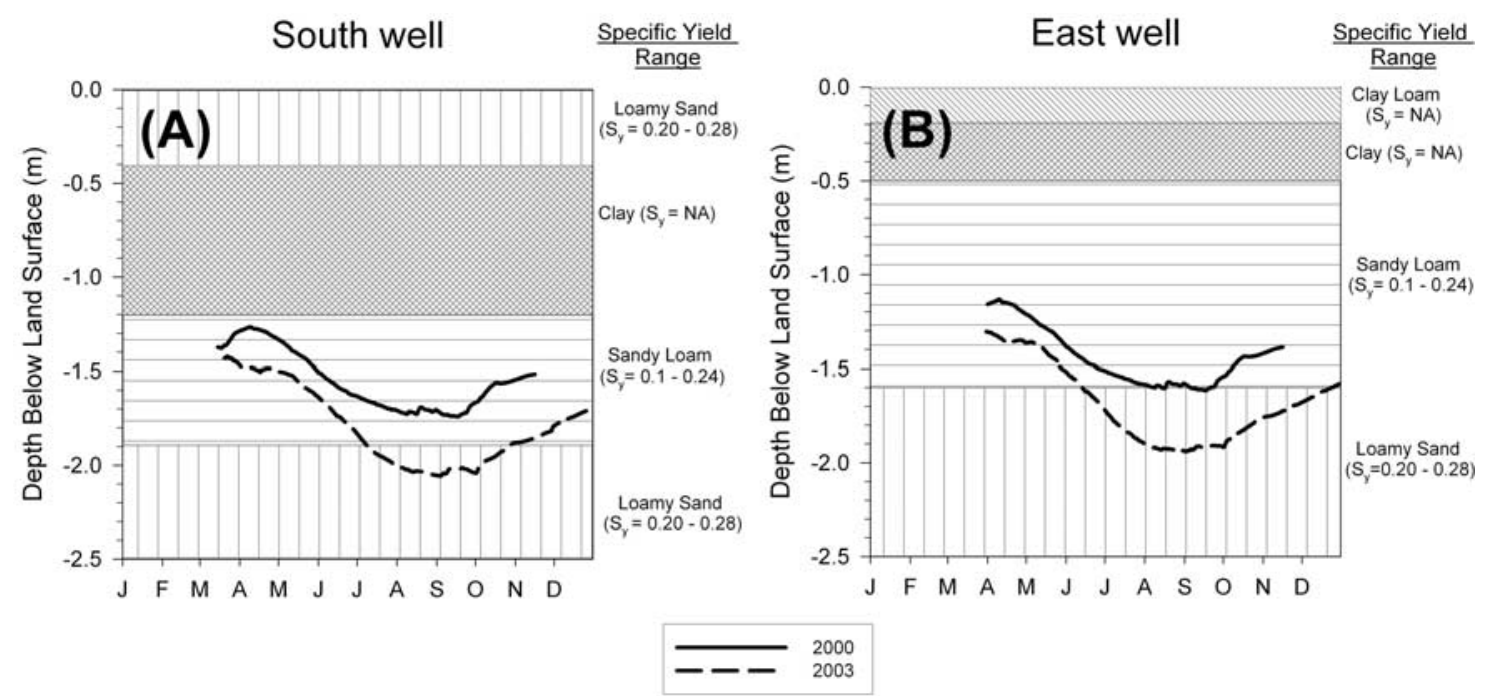

Figure 5. Vertical profile of soil texture and daily mean depth to groundwater at the (a) south and (b) east wells at the SEV site during 2000 and 2003. Major soil texture classification and estimated range of readily available specific yield are also shown. 

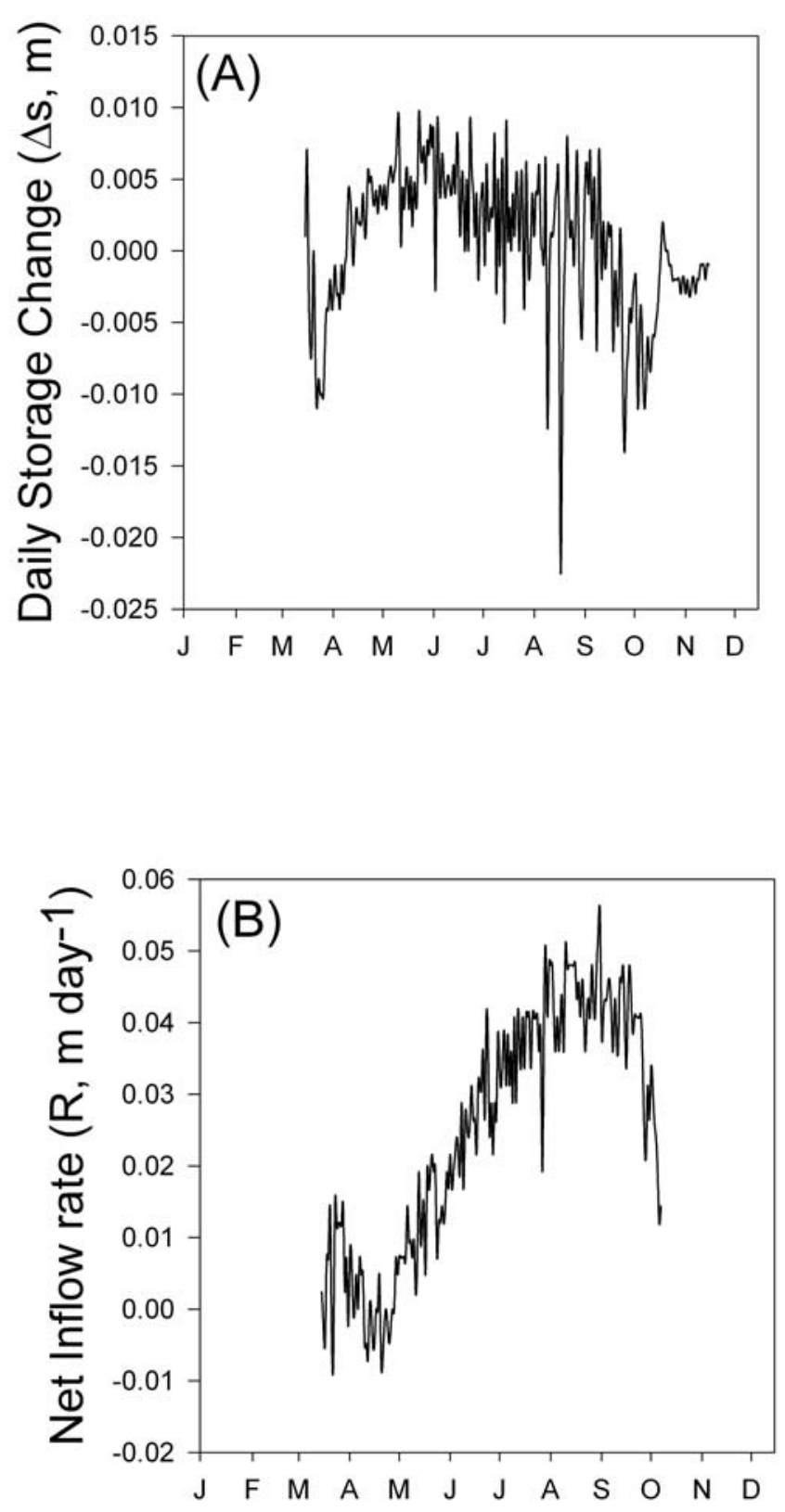

Figure 6. (a) Daily storage change $(\Delta s, \mathrm{~m})$, and (b) net inflow rate $\left(\mathrm{R}, \mathrm{m} \mathrm{d}^{-1}\right)$ at the SEV south well during 2000.

water table fluctuation zone (WTFZ) (between 0.74 and $1.21 \mathrm{~m}$ below the land surface) with a range of readily available specific yields of $0.10-0.24$. Measurements at the west and south wells of the BLN site revealed loam to sandy loam textures within the WTFZ $(0.05-1.25 \mathrm{~m})$, with a range of $S_{y}$ increasing with depth from 0.04 to 0.24 (data not shown). Clay sediments near the surface of the west well prevented estimation of $S_{y}$ in 2004 using this method [see Loheide et al., 2005]. At the SEV site, sediment profiles within the WTFZ (1.4-2.06 m) at the east and south wells are predominately sandy loam and loamy sand, with $S_{y}$ values ranging from 0.10 to 0.28 (Figure 5). Figure 5 shows the daily mean depth to groundwater and sediment textures at the south and east wells at the SEV site during
2000 and 2003. The SEV south well had a clay lens with a small $S_{y}$ at depths of $40-120 \mathrm{~cm}$. The east and north wells of the BDA site exhibited more clay lenses within the WTFZ $(0.62-1.79 \mathrm{~m})$ relative to the other sites, limiting $S_{y}$ estimates. Nevertheless, a range of soil textures was identified at BDA, including silt clay loam, clay loam, sandy loam, and loamy sand, with $S_{y}$ from 0.01 to 0.28 . An increase in finersized sediments was observed at the BLN and BDA sites as compared with ALB and SEV.

\subsubsection{Daily Change in Storage $(\Delta s)$ and Net Inflow Rate $(R)$ Estimates}

[26] Figure 6 shows the $\Delta s$ and $R$ at the SEV south well during 2000. In general, $\Delta s$ and $R$ measurements were similar between wells within a site (data not shown), especially at ALB and SEV. There were slight variations in $\Delta s$ and $R$ measurements between wells at the BLN site, and larger variations at the BDA site. Large spikes in $\Delta s$ and $R$, as shown in Figure 6 during the month of August, were subsequently removed from the data after processing $E T_{g}$ for outliers that corresponded to water table fluctuations during river pulses (refer to methods for details). In general, all sites exhibited similar curve shapes for annual $\Delta s$ and $R$ measurements. The shape of the $\Delta s$ curve typically was flat with an annual mean of 0 and variability predominately within $\pm 0.05 \mathrm{~m}$. The annual curve of $R$ measurements typically was more bell shaped, with greater recovery rates occurring during the growing season, and reduced rates during the winter months. Peak recovery rates for all sites did not exceed $0.1 \mathrm{~m} \mathrm{~d}^{-1}$.

\subsubsection{Visual Comparisons of Evapotranspiration Estimates}

[27] $E T_{g}$ ranges were similar for each well within a site, indicating similarity in the groundwater hydrographs and sediment profiles. Figures 7 and 8 show the comparison of the well $E T_{g}$ and $E T$ at the ALB site (west well) and the SEV site (south well), respectively, over the study period. At both sites, the annual onset and cessation of $E T_{g}$ closely tracked the ramp-up (April-May) and ramp-down periods (September-October) in ET. The range of $E T_{g}$ is reduced during the rising and falling limbs, as compared with the peak season (June-August), due to the lower values of $R$ and $\Delta s$. Although $E T_{g}$ and $E T$ measure two different quantities in equation (1), they both appear to track each other well.

[28] At the ALB site, $E T_{g}$ tended to be larger than tower $E T$ even when accounting for potential uncertainties in $S_{y}$. Note that the ALB site experienced understory vegetation removal in 2003 (see section 4.3), which would affect both $E T_{g}$ and $E T$ at the riparian site. It appears that the difference between the two ET estimates decreased after understory removal (2003). In contrast, comparisons at the SEV site between the south well $E T_{g}$ and tower $E T$ exhibited a closer agreement for most of the record (Figure 8). Groundwater $E T_{g}$ estimates at the SEV site clearly envelope the colocated tower ET estimates during peak season, suggesting that the White method can provide moderate estimates of riparian evapotranspiration. Note that the uncertainty captured in $S_{y}$ allows the $E T_{g}$ estimates to bound the tower $E T$ for the peak growing season. $E T_{g}$ overestimates ET (September through October) in 2003-2005 (Figure 8). These time periods correspond to a transition in water table elevation from sandy loam texture to loamy sand texture. As a result, the 
2000

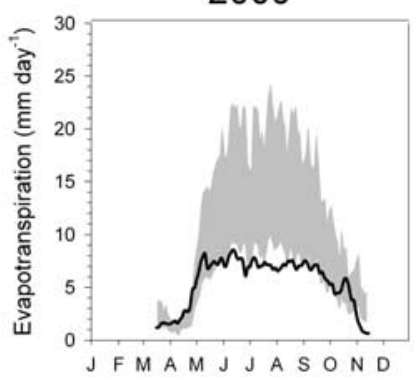

2003

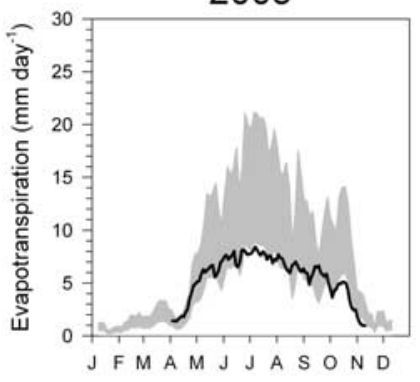

2001

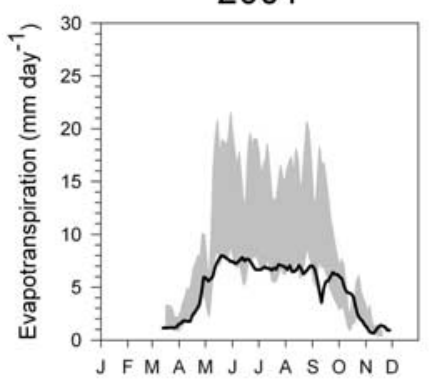

2004
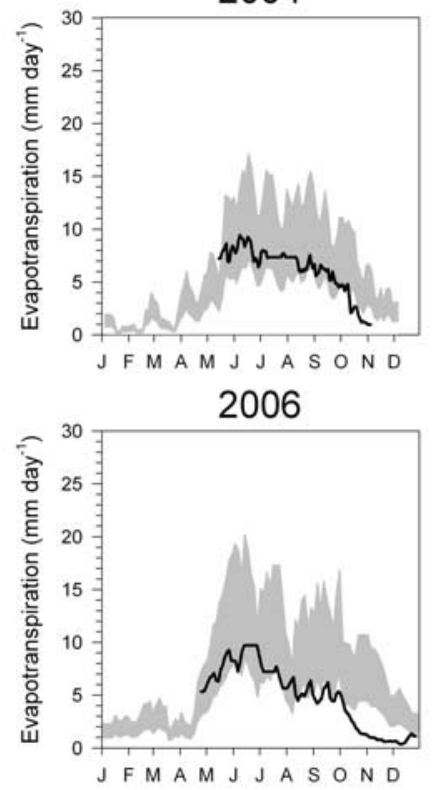

2002

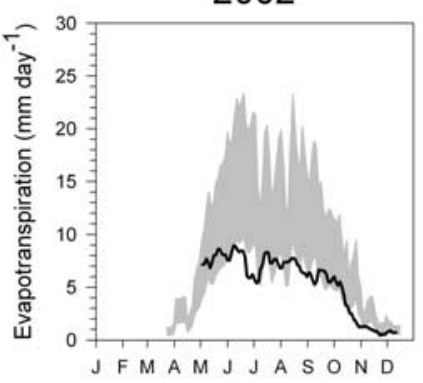

2005

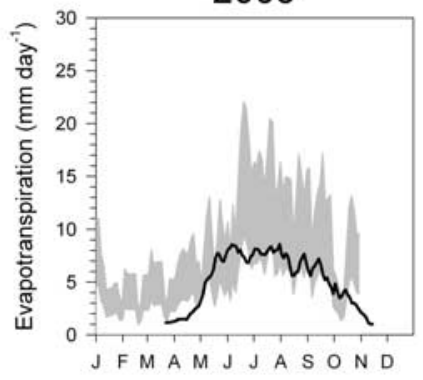

$\square$ Well ETg range Tower ET

Figure 7. Multiple-year comparison of $E T$ (solid curve) and west well $E T_{g}$ range (gray region) for the ALB site for years 2000-2006. Estimates of ET and $E T_{g}$ are represented as 10-day running averages. Units are in $\mathrm{mm} \mathrm{d}^{-1}$.

modeled range in $S_{y}$ went from $0.1-0.24$ to $0.2-0.28$ (Figures 4 and 5), reducing well $E T_{g}$ range and overestimating ET. ET $T_{g}$ estimates at the SEV site (salt cedar) are significantly reduced as compared with the ALB site (Figures 7 and 8).

[29] At the BLN site, the west well $E T_{g}$ exhibits lower variations and encompasses the tower $E T$, while the south well overestimates ET and shows large fluctuations (data not shown). At the BDA site, neither well $E T_{g}$ estimate captures the tower ET (data not shown). During most of the year, $E T_{g}$ at the BDA east well could not be calculated because the water table was located within sediments composed of $40 \%$ clay or more, and when possible, the values were extremely low due to corresponding low $S_{y}$ estimates. While soil profile conditions at the BDA north well did not limit $E T_{g}$ estimates, these exhibited erratic behavior that overestimated or underestimated tower ET and did not capture the ramp-up and ramp-down periods.

\subsubsection{Statistical Comparisons of Evapotranspiration Estimates}

[30] Table 1 shows the percent coefficient of variation $(\mathrm{CV} \%)$ calculated over the peak growing season (JuneAugust) for the daily tower ET and $E T_{g}$ estimates. CV\% was calculated by dividing the standard deviation over the season $(\sigma)$ by the seasonal mean $(\mu)$ for $E T_{g}$ and $E T$ during each year $(\mathrm{CV} \%=100 \sigma / \mu)$. The $\mathrm{CV} \%$ values for $E T_{g}$ were averaged between high and low estimates of $S_{y}$. Yearly values of $\mathrm{CV} \%$ were then averaged over the $2000-2006$ period. At all four sites, $\mathrm{CV} \%$ of $E T_{g}$ is greater than $\mathrm{CV} \%$ of $E T$. Wells within a site have similar variability in $E T_{g}$ estimates, except at the BDA site where the east well has larger CV\%. At ALB and $\mathrm{SEV}, \mathrm{CV} \%$ of $E T_{g}$ was closer to the $\mathrm{CV} \%$ of $E T$, whereas the BLN and BDA sites have nearly 3-6 times more variability in $E T_{g}$ than in $E T$ (Table 1). It should be noted that east well $\mathrm{CV} \%$ at BDA represent only 1 year, whereas $\mathrm{CV} \%$ at the north well represents a 6-year average.

[31] Table 2 presents the $E T_{g}$ and ET averaged over the 92-day peak growing season (June-August) over the record period. The range of $E T_{g}$ estimated at each well at the ALB site overlapped with tower ET values in four (2003-2006) of the seven years. ALB peak season $E T_{g}$, averaged across the record and each well, captured $97.3-233.81 \%$ of average $E T\left(7.20 \mathrm{~mm} \mathrm{~d}^{-1}\right)$. South and west well $E T_{g}$ values at ALB were significantly correlated to $E T(\mathrm{r}=0.5, \mathrm{p}<$ 0.001 ), except in 2006 (Table 3). At the SEV site, south and east well $E T_{g}$ had the highest average correlation with $E T$ ( $\mathrm{r}=0.71$ and 0.61 , Table 3 ). The $E T_{g}$ range of the south well overlapped with ET during 6 years, whereas the east well 

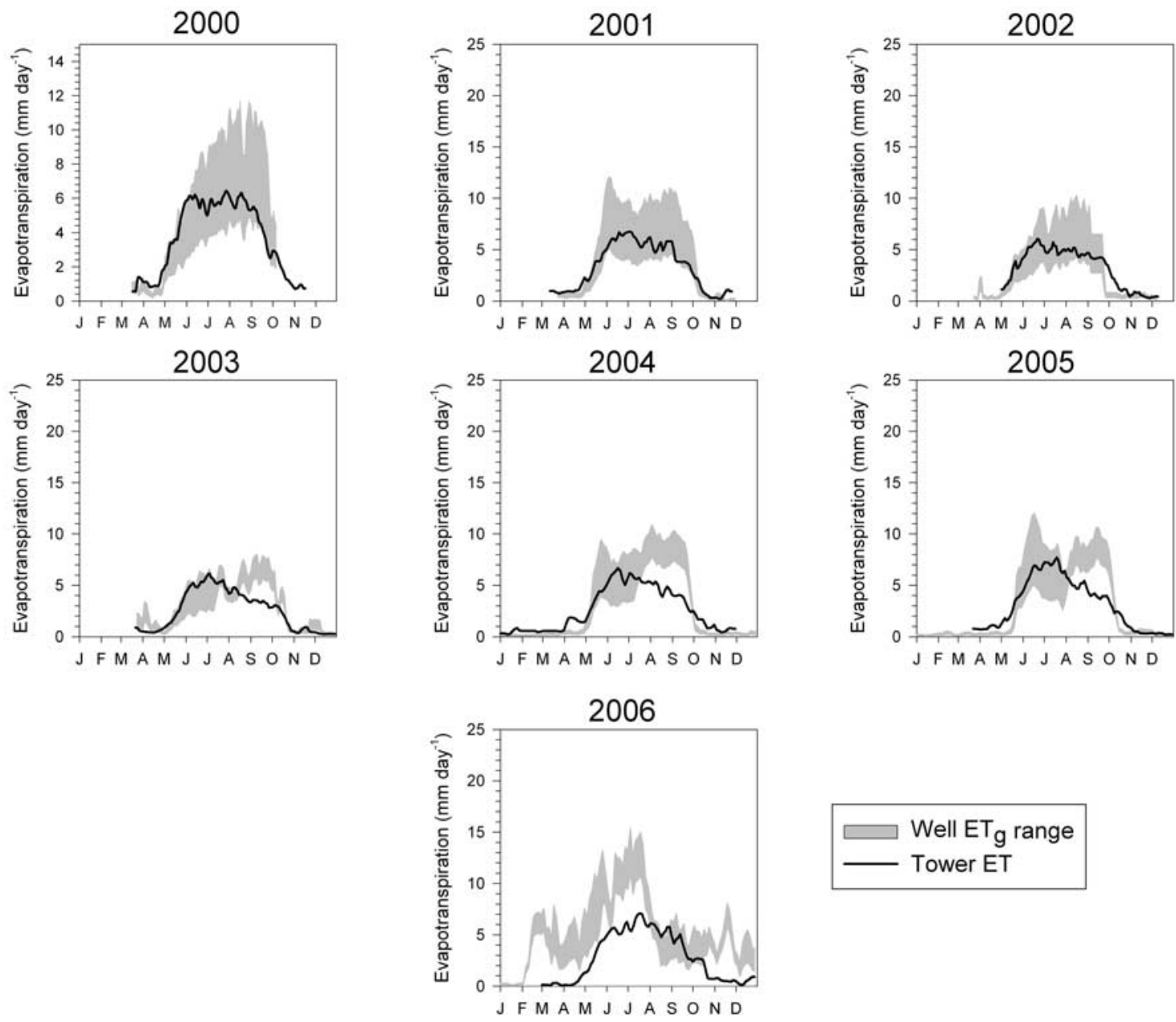

Figure 8. Multiple-year comparison of $E T$ (solid curve) and south well $E T_{g}$ range (gray region) for the SEV site for years 2000-2006. Estimates of ET and $E T_{g}$ are represented as 10-day running averages. Units are in $\mathrm{mm} \mathrm{d}^{-1}$.

only overlapped 2 years (Table 2). South well $E T_{g}$ values ranged from $79.7 \%$ to $155.2 \%$ of the tower measurement, while east well $E T_{g}$ ranged from $103.2 \%$ to $174.3 \%$ of $E T$. At BDA, the north well $E T_{g}$ overlapped the tower $E T$ for 3 years, but on average was $113.5 \%$ to $273.6 \%$ larger. At BDA, 2001 was the sole year when $E T_{g}$ was correlated to $E T(\mathrm{r}=0.83)$. Correlation between the BDA north well and the $E T$ was stronger $(\mathrm{r}=0.31)$ across the record as compared with the east well $(\mathrm{r}=0.01)$. At the BLN site, $E T_{g}$ values at the west well enveloped the tower ET during the 4 years, whereas the south well overlapped for only 2 years (Table 3 ). On average, south and west well $E T_{g}$ differed from $E T$ by $120.9 \%$ and $81.3 \%$ for the low $S_{y}$ range (Table 2). BLN peak season $E T_{g}$, averaged across the record and each well, captured $101.1-254.3 \%$ of average $E T\left(6.17 \mathrm{~mm} \mathrm{~d}^{-1}\right)$. A weak correlation was found between $E T$ and $E T_{g}(\mathrm{r}=0.26)$. Among all the sites, $E T_{g}$ estimates at the $\mathrm{SEV}$ site were closest to ET.

\subsection{Using Groundwater Hydrographs to Assess Understory Vegetation Removal}

[32] Figure 9 presents 10-day running averages of the diurnal amplitude $(\Delta a)$ of groundwater fluctuations for three wells at ALB during 2001 (April-October). Also depicted are the tower $E T$ and range of $E T_{g}$ derived from the west well. The diurnal amplitude $(\Delta a)$ of a given day is calculated by subtracting the maximum and minimum water table elevations over a $24-\mathrm{h}$ period. Note how $\Delta a$ and $E T_{g}$ closely track tower $E T$ during the growing season and capture the onset and demise of seasonal $E T_{g}$. Leaf area index (LAI) declined from an average of 6.67 during the preremoval years to approximately 4 in 2003 (40\% reduction) (Figure 10). Total LAI measured in 2006 remained $47 \%$ lower than preremoval estimates. Throughout the entire study period, the summer peak season average $\Delta a$

Table 1. Percent Coefficient of Variation for Estimates of $E T_{g}$ and ET at ALB, BLN, SEV, and BDA Sites, Computed Over the Peak Growing Season (June-August) for 2000-2006 ${ }^{\mathrm{a}}$

\begin{tabular}{lccc}
\hline \hline Site & South $E T_{g}$ & West $E T_{g}$ & Tower $E T$ \\
\hline ALB & $33( \pm 6)$ & $34( \pm 7)$ & $18( \pm 4)$ \\
BLN & $65( \pm 25)$ & $67( \pm 24)$ & $19( \pm 3)$ \\
SEV & $30( \pm 14)$ & $40( \pm 11)$ & $17( \pm 2)$ \\
\hline & East $E T_{g}$ & North $E T_{g}$ & Tower $E T$ \\
\hline BDA & $129($ nd $)$ & $74( \pm 48)$ & $17( \pm 3)$ \\
\hline \hline
\end{tabular}

${ }^{\mathrm{a}}$ Standard deviations (SD) are given in parenthesis. 
ranged from 4.5 to $6 \mathrm{~cm}$, whereas during the winter, $\Delta a$ ranged from 0 to $1 \mathrm{~cm}$. Note how vegetation removal is reflected in the reduction of daily amplitude of groundwater fluctuations, in particular during the year following removal (2004).

[33] Figure 11 presents 10-day running averages of diurnal $\Delta a$ at the center, west, and south wells prior (20002002) and after (2004-2006) vegetation understory removal. Postrestoration $\Delta a$ exceeded prerestoration $\Delta a$ during April and October. Groundwater amplitude of the preremoval period ranged from $1.0 \mathrm{~cm}$ in winter to $6.0 \mathrm{~cm}$ during the growing season, while postremoval $\Delta a$ varied from 2.0 to $5.5 \mathrm{~cm}$ (Figure 11). A Mann-Whitney test indicated that $\Delta a$ was significantly reduced in postremoval years $(\mathrm{p}<$ $0.001)$. The difference in the median amplitude across the three wells was $0.32-0.86 \mathrm{~cm}$ (at 95\% confidence level), which represents a $6.7-18.1 \%$ reduction in $\Delta a$. Peak season $E T_{g}$ during the postremoval years showed a 19 $21 \%$ reduction as compared with the preremoval years (Table 2).

\section{Discussion}

\subsection{Riparian Evapotranspiration and Groundwater Hydrographs}

[34] In the semiarid southwestern United States, there is a growing effort to construct regional water budgets to aid in water management decisions. A major component of the water budget in riparian ecosystems is evapotranspiration [e.g., Dahm et al., 2002; Cleverly et al., 2006a, 2006b; Newman et al., 2006]. Dahm et al. [2002] estimated the annually averaged riparian ET in the Middle Río Grande as 150 to $250 \times 10^{6} \mathrm{~m}^{3} / \mathrm{a}$, which accounted for $20-30 \%$ of water consumption from Otowi gauge to Elephant Butte Reservoir. Although few studies have identified contributions of evaporation and transpiration, a significant portion of total evapotranspiration in semiarid riparian ecosystems can occur from vegetative consumption of groundwater [e.g., Ferretti et al., 2003; Yepez et al., 2003; Scott et al., 2005; Lauenroth and Bradford, 2006; Steinwand et al., 2006]. Research along the San Pedro River in Arizona revealed that transpiration accounted for close to $100 \%$ of the total riparian water loss during dry periods, and near $35 \%$ during large precipitation events that led to an increase in soil evaporation [Corell et al., 1996; Goodrich et al., 2000; Yepez et al., 2003; Leenhouts, 2005; Scott et al., 2005]. The majority of the total transpiration (71-94\%) during the peak and late summer months was attributed to the overstory vegetation, whose primary source was groundwater [Scott et al., 2005]. As a result, the dynamics of the riparian vegetation and its effect on groundwater are critical to understand local and regional water budgets in the southwestern United States.

[35] Exploring the relationships between groundwater dynamics, riparian evapotranspiration, and long-term trends in ecosystem structure and function is still difficult due to the lack of accurate $E T$ measurements at appropriate scales in riparian zones of different widths [e.g., Thorburn et al., 1993; Tabacchi et al., 2000; Dahm et al., 2002; Cleverly et al., 2002; Shafroth et al., 2005; Wilcox et al., 2006]. In this study, we have used long-term meteorological flux tower and groundwater hydrograph data to compare the 3SEC and 
Table 3. Annual and Record Correlation Coefficients of $E T_{g}$ at Specific Wells and Tower $E T$ for ALB, BLN, SEV, and BDA Sites Over $2000-2006^{\mathrm{a}}$

\begin{tabular}{|c|c|c|c|c|c|c|c|c|c|c|}
\hline Site & Correlation & 2000 & 2001 & 2002 & 2003 & 2004 & 2005 & 2006 & Record Average ${ }^{b}$ & SD \\
\hline \multirow[t]{3}{*}{ ALB } & south-west & 0.99 & 0.48 & 0.99 & 0.76 & 0.99 & 0.49 & 0.86 & 0.79 & 0.23 \\
\hline & south-tower & 0.59 & 0.61 & 0.61 & 0.56 & 0.37 & 0.27 & $0.513^{\mathrm{c}}$ & 0.50 & 0.13 \\
\hline & west-tower & 0.59 & 0.62 & 0.61 & 0.52 & 0.39 & 0.29 & N.D. & 0.50 & 0.13 \\
\hline \multirow[t]{3}{*}{ BLN } & south-west & 0.42 & 0.44 & $0.15^{\mathrm{c}}$ & 0.36 & 0.36 & N.D. & N.D. & 0.35 & 0.12 \\
\hline & south-tower & 0.36 & 0.34 & $0.001^{\mathrm{c}}$ & 0.34 & $0.261^{\mathrm{c}}$ & N.D. & N.D. & 0.26 & 0.15 \\
\hline & west-tower & $0.149^{\mathrm{c}}$ & 0.28 & $0.20^{\mathrm{d}}$ & 0.41 & $0.326^{\mathrm{d}}$ & N.D. & N.D. & 0.27 & 0.10 \\
\hline \multirow[t]{3}{*}{ SEV } & south-east & 0.959 & 0.82 & 0.79 & 0.48 & 0.55 & 0.66 & 0.51 & 0.68 & 0.18 \\
\hline & south-tower & 0.753 & 0.818 & 0.832 & N.D. & 0.72 & 0.71 & 0.45 & 0.71 & 0.14 \\
\hline & east-tower & 0.704 & 0.66 & 0.73 & N.D. & 0.51 & 0.63 & 0.413 & 0.61 & 0.12 \\
\hline \multirow[t]{3}{*}{ BDA } & north-east & N.D. & N.D. & N.D. & 0.87 & N.D. & $-0.108^{c}$ & N.D. & 0.38 & 0.69 \\
\hline & north-tower & $0.285^{\mathrm{c}}$ & 0.827 & $-0.149^{c}$ & $0.03^{\mathrm{c}}$ & $0.47^{\mathrm{c}}$ & $-0.127^{\mathrm{c}}$ & 0.82 & 0.31 & 0.42 \\
\hline & east-tower & N.D. & N.D. & N.D. & $-0.01^{\mathrm{c}}$ & $0.3^{\mathrm{c}}$ & $0.157^{\mathrm{c}}$ & $-0.396^{\mathrm{c}}$ & 0.01 & 0.30 \\
\hline
\end{tabular}

${ }^{a}$ The Pearson correlation tests for linear correlation between both wells and tower. All coefficients are significant at $\mathrm{p}<0.001$, unless noted otherwise. N.D. means no data.

${ }^{\mathrm{b}}$ Values are averaged for all years data are available.

${ }^{\mathrm{c}}$ Not significant.

${ }^{\mathrm{d}}$ Significant at $\mathrm{p}<0.05$.

White methods for estimating riparian evapotranspiration and to monitor the hydrologic effects of changing vegetation density. However, the influence of river flood pulses on the White method must be accounted for in riparian corridors with perennial reaches and high levels of hydrologic connectivity between the river and shallow aquifer. Typically, these variations were caused by large river pulses during snowmelt and monsoon seasons. The BLN and BDA sites showed the largest river-induced groundwater fluctuations, while the SEV site was mostly unresponsive to shortterm fluctuations (Figure 3). The surface water/groundwater connectivity at the ALB site, although less than BLN and $\mathrm{BDA}$, did result in increased temporal variations in $E T_{g}$, especially during wetter years (e.g., 2004-2006).

[36] We found that $E T_{g}$ estimates at all four sites along the Río Grande riparian corridor have large variability due to the inherent uncertainty in specific yield $\left(S_{y}\right)$. We utilized the coefficient of variations $(\mathrm{CV} \%)$ between the tower $E T$ and groundwater $E T_{g}$ estimates to determine whether a comparison of the methods was appropriate [Lauenroth and Bradford, 2006]. A greater similarity in CV\% suggests that a closer relationship exists at the ALB and SEV sites, as compared with the BLN and BDA sites (Table 1). Differences in sediment composition in the zone of water table fluctuations may explain some of the observed variability in the groundwater $E T_{g}$ estimates. As shown in previous studies, $E T_{g}$ calculations using the White method can overestimate or underestimate actual ET depending on the values of the specific yield $\left(S_{y}\right)$ assumed for the sediments that interact with the water table [e.g., Healy and Cook, 2002; Loheide et al., 2005; Butler et al., 2007; Lautz, 2008]. Various studies have documented how $S_{y}$ estimates for coarse sediments have lower uncertainties [e.g., Rosenberry and Winter, 1997; Healy and Cook, 2002; Loheide et al., 2005; Butler et al., 2007]. Since coarser sediments drain more quickly, errors in estimating $S_{y}$ related to drainage and retention times are minimized. Finer textures (i.e., silt and clay) tend to decrease hydraulic conductivity and increase water retention. As a result, estimates of $E T_{g}$ may not respond as readily within a $24-\mathrm{h}$ cycle if the water table is located within silt and clay dominated sediments. Both ALB and SEV sites had deeper water tables that interacted with coarser sediments (loamy sand to sandy loam) as compared with BLN and BDA where shallower water tables were located in soils with finer particles (sandy loam to silty clay loam). The stronger correlation between $E T_{g}$ and $E T$ at ALB and SEV indicates these sites are more amenable for the White method. The SEV site was found as the best candidate to estimate $E T_{g}$ as groundwater is typically deeper than $1 \mathrm{~m}$ from the surface and the connectivity between the river and shallow aquifer is minimal.

[37] We found that the range of $E T_{g}$ values was larger than tower $E T$ measurements at all four study sites. While $E T_{g}$ can envelope tower $E T$ at certain sites, the daily variations in water table can lead to greater variability in evapotranspiration estimates than the daily meteorological flux estimates. While this result may seem counterintuitive, it is clear that the White method is sensitive to potential errors in estimating $S_{y}$ and can be influenced by periods of hydrologic fluxes from the nearby river. Nevertheless, we accounted for both sources of error by excluding periods of large diurnal changes not related to plant transpiration and by sampling a range of possible $S_{y}$. The two sites with the

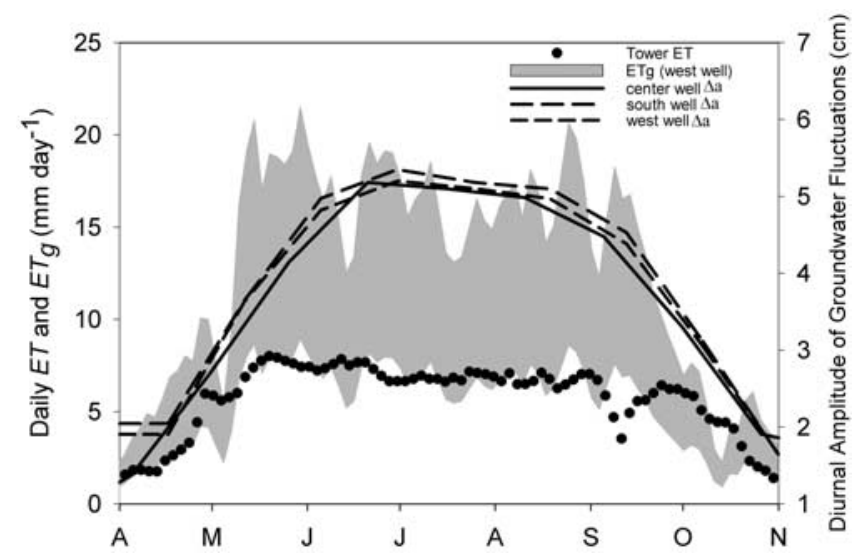

Figure 9. Diurnal amplitude $\Delta a(\mathrm{~cm})$ of groundwater fluctuations at center, south, and west wells (curves), daily $E T\left(\mathrm{~mm} \mathrm{~d}^{-1}\right)$ (dots) at the ALB site, and $E T_{g}\left(\mathrm{~mm} \mathrm{~d}^{-1}\right)$ (gray area) from the west well during 1 April to 31 October 2001. 


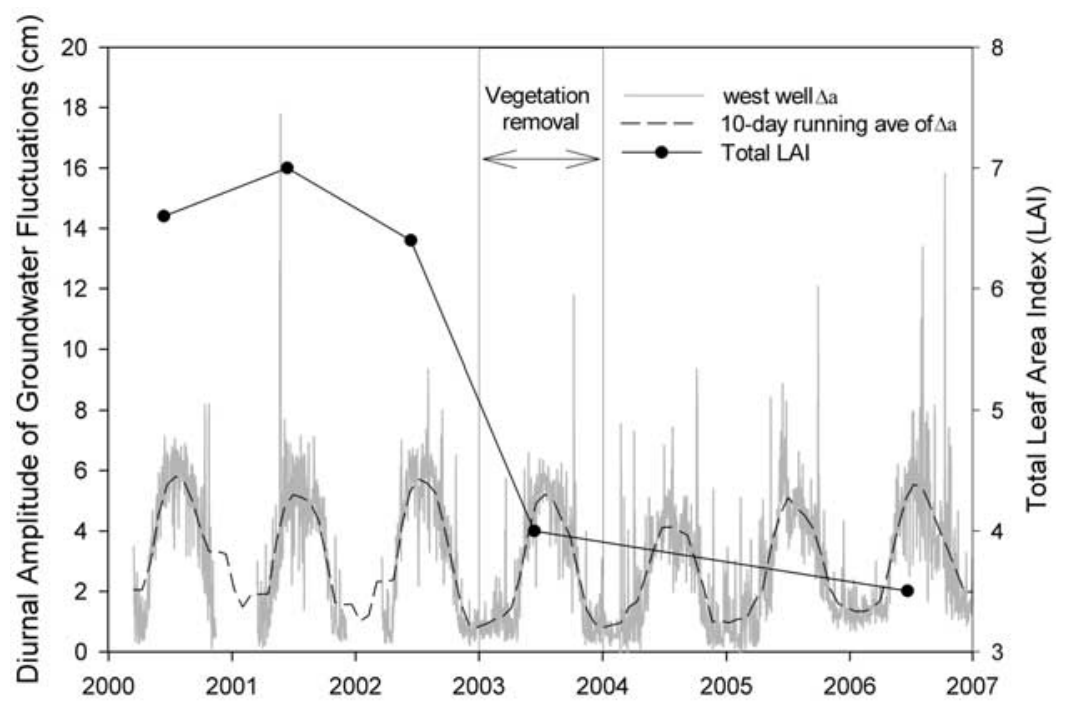

Figure 10. Diurnal amplitude $\Delta a(\mathrm{~cm})$ of groundwater fluctuations (gray curve) and field estimates of total leaf area index (LAI) (solid curve) at the ALB center well from 2000 to 2006. Diurnal amplitudes are shown with a 10-day running average (dashed curve). Box highlights the year that understory vegetation was removed.

strongest correlations between $E T$ and $E T_{g}$ were ALB and SEV (Figures 7 and 8). The lower range of $E T_{g}$ estimates at the ALB and SEV sites were on average 97.3 and $101.1 \%$ of the tower $E T$ estimates. While this result is encouraging, the higher ranges of $E T_{g}$ estimates based on high $S_{y}$ values were 233.8 and $164.8 \%$ of $E T$. $E T_{g}$ appears to be the primary component of total $E T$ compared with $E_{o}, E_{i}$, and $E T_{S}$ (see equation (1)), especially at the ALB site. Compared with the ALB site, the groundwater at the SEV site is consistently deeper and less connected to the river, making vadose zone water $\left(E T_{s}\right)$ a potentially more important component of total ET. Furthermore, salt cedar plants, the primary vegetation at the SEV site, have a greater ability to extract water from the vadose zone than do cottonwood plants, the primary vegetation at the ALB site. Thus combining both the White method and 3SEC method can help separate the $E T_{g}$ component from total $E T$, and reveal how vegetation types can alter the balance of $E T$ components.

[38] The SEV site exhibited the best correlation between $E T$ and $E T_{g}$ due to the improved measurements of available specific yield that can be obtained when the groundwater is deeper than $1 \mathrm{~m}$ and sediment texture is well known [Loheide et al., 2005; Butler et al., 2007]. While depth to groundwater at all four sites occasionally dropped below $1 \mathrm{~m}$, only the SEV site had a water table position consistently below $1 \mathrm{~m}$. As discussed by Loheide et al. [2005], the depth to groundwater, the degree of hydrologic connectivity, and the sediment composition are critical factors in applying the White method. In 2006, there was a clear increase in overestimation of $E T$ and variability associated with $E T_{g}$. This variability between February and March can be explained by an increase in recovery rate $(R)$ estimates, beginning suddenly in mid-February, which was not apparent during the previous years (data not shown). The sudden increase in $R$ in mid-February is not explained by river stage fluctuations, which were relatively calm during this period. It is worth noting that during January and July of 2006, the water level position was at its lowest depth on record $(\sim-2.0 \mathrm{~m})$. Even though the water table was located within a sandy loam texture from mid-March to June, $E T_{g}$ still overestimated ET. There is insufficient evidence to determine whether the rapid fluctuations in $R$ are caused by additional inflows, such as regional groundwater flows or an increase in capillary flow. In addition to the variability associated with $S_{y}$, another reason why $E T_{g}$ overestimates ET could be artificially high recovery rates (R). While $\mathrm{R}$

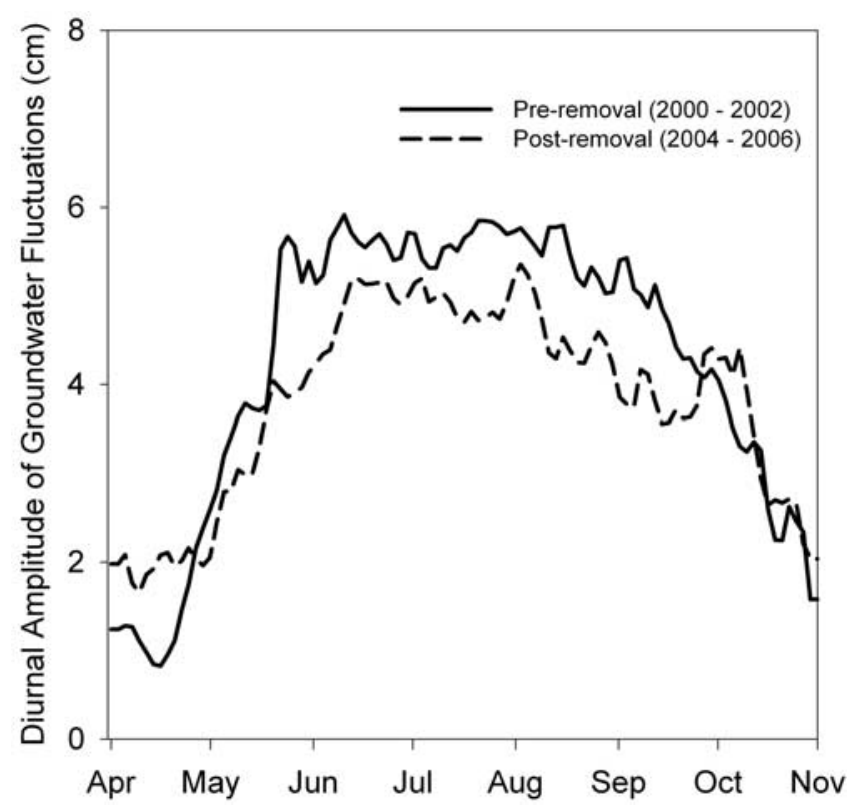

Figure 11. Diurnal amplitude $\Delta a(\mathrm{~cm})$ of groundwater fluctuations averaged for three wells at the ALB site during the growing season (1 April to 31 October). Solid curve represents the preremoval period, and the dashed curve represents the postremoval period. The data are shown as 10 -day running averages. 
appears to change with vegetation growth (increasing during the growing season) and local hydrologic conditions, it is not clear what factors influence $\mathrm{R}$ throughout the day. More research is needed on the diurnal changes of $\mathrm{R}$ in relationship to river stage height, groundwater fluctuations, and vegetation growth. This research is needed in order to know whether or not calculating $\mathrm{R}$ from midnight to 0400 LT. is an accurate approach to estimate R. Although daily groundwater hydrographs can be highly variable in both space and time, they have been shown to capture distinct patterns among different sites, and therefore can potentially be used to capture significant changes within a site.

[39] Spatial variation in groundwater responses will influence the estimation of $E T_{g}$ in riparian corridors, depending on the composition of alluvial aquifer sediments and spatial gradients in groundwater elevation. Spatial groundwater differences in wells $40 \mathrm{~m}$ apart at each site generally produced identical groundwater hydrographs, resulting in similar temporal patterns in depth to groundwater, storage $(\Delta s)$, and recovery rate $(R)$ (Figure 6). Although exceptions exist, differences between well estimates of $E T_{g}$ at each site appear more correlated with spatial variability in $S_{y}$ than with variations of $\Delta s$ and $R$. At the ALB and SEV sites, the similarity between $E T_{g}$ estimates at both wells is a result of similar sediment textures and groundwater well hydrographs (see Figure 5 for SEV). However, the correlation coefficients between $E T_{g}$ estimates at the ALB and SEV site were relatively lower during some years (e.g., 2001 and 2005 for ALB, and 2003 for SEV). One possible explanation for the lower correlation coefficients at the ALB site is that 2001 and 2005 were both significantly wetter years (larger river flows). Significant river stage changes during these years are likely influencing the spatial groundwater dynamics at hydrologically connected sites such as ALB even after removing the effects of large river pulses on the groundwater. In the case of SEV, 2003 was a significantly drier year, which resulted in some of the deepest mean water table depths at this site (Figure 5). Perhaps the difference in spatial groundwater fluctuations between wells at the SEV site became more evident as the water table moved across heterogeneous sediment layers, as shown in Figure 5. The correlation coefficient of $E T_{g}$ at both ALB and SEV sites suggests that nearby wells might respond differently to raised or lowered water table positions, as controlled by local hydrological conditions. In addition, estimates of $E T_{g}$ using the White method should account for the temporal interactions of the water table with different $S_{y}$ zones (and the uncertainty in $S_{y}$ for each layer). It is therefore advisable to have multiple wells around a meteorological flux tower in order to select the most appropriate groundwater hydrograph records.

[40] In contrast, BLN west and south wells had similar hydrographs but interact with different soil horizons with varying $S_{y}$. In most years, the BLN west well had greater $\Delta a$ values but nearly half of the $E T_{g}$ variability than the south well. The larger $E T_{g}$ fluctuations at the south well can further be explained by the greater $S_{y}$ ranges at the south well compared with the west well. Because of finer textures, $E T_{g}$ estimates at the west well may have higher timedependent errors than the south well that may result in a decreased correlation with ET [Rosenberry and Winter, 1997; Healy and Cook, 2002]. However, record average correla- tions between south and west well $E T_{g}$ and $E T$ were similar (0.26 and 0.27 ) despite the differences in coarse sediments and groundwater elevation. While this result suggests that readily available $S_{y}$ [Loheide et al., 2005] can be adequately predicted from soil texture at sites with a shallow water table and fine-textured sediments, it clearly does not hold true at the BDA site. In this study, the White method performed better in loam-dominated sediments, such as the BLN west well, compared with clay loam and silt clay loam sediments, as was the case at the BDA north well. In 2003, groundwater at the BLN west well transitioned during June from a loam layer to a sandy loam layer, while groundwater in the south well consistently occupied a sandy loam layer. This groundwater shift at the west well resulted in an increase in the range of $E T_{g}$. In 2004, the BLN wells showed larger groundwater fluctuations due to a relative increase in river stage variations, resulting in larger $E T_{g}$ ranges. The increased river stage fluctuations might be explained by nearby irrigation operations. This indicates that caution must be taken in applying the White method in riparian areas where groundwater is highly responsive to surface water forcings, particularly during wetter periods, which include seasonal river pulses, daily phreatophyte water consumption, and surface water diversion and pumping effects. Overall, temporal variation in depth to the water table will influence estimation of $E T_{g}$ as daily interactions occur with different soil horizons.

[41] It is apparent that $E T_{g}$ estimates are sensitive to vertical heterogeneity in $S_{y}$ and its possible spatial variations. It is therefore prudent to have at least two riparian wells located in close proximity to obtain a baseline understanding of site heterogeneity. Variations between $E T_{g}$ and $E T$ appear to increase as the water table approaches the land surface. At some sites, estimates of $E T_{g}$ were limited by fine sediments and river fluctuations. In our study, BLN and BDA exhibited the weakest correlation between $E T_{g}$ and $E T$, possibly due to the presence of fine sediments in the soil column. The erratic behavior at BDA north well was a result of very large fluctuations in $\Delta s$. Clearly, the application of the White method for estimating $E T_{g}$ can fail under particular conditions. As demonstrated by comparing the SEV site with ALB and BLN sites, $E T_{g}$ estimates using the White method improved when water table fluctuations stabilized at deeper positions, were located in coarser sediments, and were less hydrologically connected to local surface water fluctuations. In order to minimize the large uncertainties associated with specific yield estimates, in situ measurements (e.g., aquifer pump test or soil-moisture profile analysis) of specific yield might be needed, especially at sites where groundwater is shallower and interacts with finer sediments.

\subsection{Understory Vegetation Removal and Groundwater Hydrographs}

[42] Recent evaluations of vegetation restoration projects note a lack of monitoring data following the restoration activity [Bernhardt et al., 2005; Palmer et al., 2005], which limits the long-term evaluation of restoration efforts [e.g., Wissmar, 2004; Wohl et al., 2005]. For example, restoration projects have not adequately tracked water salvage, if any, even though this was often cited as a motivating reason for the restoration [e.g., Culler et al., 1982; Bernhardt et al., 2005; Palmer et al., 2005; Wilcox et al., 2006; Wilcox and 
Thurow, 2006]. Culler et al. [1982] evaluated evapotranspiration along a $24-\mathrm{km}$ reach in southern Arizona before and after the removal of floodplain vegetation. Long-term hydrologic monitoring revealed that vegetation removal led to an increase in annual groundwater discharge to the river following removal, particularly during the summer. Welder [1988] analyzed 15 years of water table and base flow data following the cutting of 19,000 acres (7689 ha) of salt cedar along the Pecos River in New Mexico. Water salvage was detected along the reach but did not result in significant increases to river base flow. Stednick [1996] compiled the results from paired catchment studies that looked at the effects of timber harvesting on annual water yield and concluded that the hydrometeorological conditions and the basal extent of the timber harvest were critical factors.

[43] Monitoring daily groundwater fluctuations in riparian ecosystems can be an effective tool to assess impacts of vegetation removal on hydrological resources [Steinwand et al., 2006; Zhang and Schilling, 2006]. Here, we analyzed 3 years of daily groundwater data at the ALB site prior to and after the removal of dense understory exotic vegetation, primarily salt cedar (Tamarix chinensis) and Russian olive (Elaeagnus angustifolia). A small but significant change in groundwater dynamics was detected following vegetation removal. The reduction in groundwater fluctuation amplitude $(\Delta a)$ by $6.7 \%$ to $18.1 \%$ is comparable to the $9 \%$ decrease in ET following understory removal, as reported by Cleverly et al. [2006a]. The water table at the ALB site did not rise after vegetation removal. The mean water table depth $(1.38 \mathrm{~m})$ was the same for both prevegetation and postvegetation removal years. Diurnal groundwater fluctuation amplitudes $(\Delta a)$ can potentially be used as a technique to quickly inspect the effects of vegetation removal on riparian $E T$, if appropriately time averaged. The $(\Delta s+R)$ term from equation (2) can also be used in conjunction with $\Delta a$ to measure vegetation-induced changes to riparian $E T$. We found that comparing $(\Delta s+R)$ and $\Delta a$ at the ALB site produced similar variability (data not shown), which might not be the case at every riparian site. Using $\Delta a$ is particularly useful at riparian sites where water table mean depths are controlled primarily by surface water dynamics, where groundwater storage $(\Delta s)$ values tend to be low $(\Delta s \sim 0$; see Figure 6) and vegetation-induced diurnal groundwater fluctuations can be clearly determined. However, this technique will have to account for river stage influences on groundwater elevations to improve the application of $\Delta a$ to monitor changes in ET. The increase in postremoval $\Delta a$ during April and October compared with preremoval is a result of large snowmelt and monsoon events that occurred during the postremoval period. Using $\Delta a$ to monitor restoration projects might not be appropriate at riparian sites where the groundwater is hydrologically disconnected from surface water recharge (very low R). More research is needed to explore the benefits of using $\Delta a$ and $(\Delta s+R)$ to measure the changes in riparian groundwater dynamics where vegetation removal has occurred.

[44] Interestingly, we found that the reduction in $\Delta a$ is relatively small considering that the understory was a large portion of total LAI at the site. Even though LAI was significantly reduced, peak season ET showed a slight increase in 2004 and 2005 (Table 2). Furthermore, the correlation between $E T_{g}$ and $E T$ decreased in post restora- tion years (Table 3). Decreased transpiration resulting from understory vegetation removal could be offset by increased soil evaporation due to increasing the solar radiation reaching the ground surface, and could have a significant role in reducing measurable ET reductions [e.g., Zhang and Schilling, 2006]. We suspect that understory removal caused an increase in net radiation $\left(R_{n}\right)$, which resulted in an increase in $E T$. This would help to explain the reduced correlations between $E T$ and $E T_{g}$ during postrestoration years. The contribution of soil evaporation to ET measurements at this site will more likely depend on available moisture within the mulch layer derived from precipitation, rather than evaporation from soil sediments below the mulch layer. These results suggest that the cottonwood overstory at this site dominates groundwater consumption, even though the understory made up a significant portion of LAI. However, without accounting for soil evaporation and transpiration from the vadose zone, we cannot completely evaluate water salvage and the different roles that understory and overstory vegetation have on water consumption [e.g., Steinwand et al., 2006; Zhang and Schilling, 2006]. We hypothesize that in these phreatophyte-driven riparian ecosystems, $E T_{S}$ will be generally negligible compared with $E T_{g}$ (see equation (1)). Clearly, removing the dense understory of exotic vegetation at this riparian site has not resulted in large water savings, though measurable impacts are observed in groundwater diurnal fluctuations and $E T_{g}$ measurements (Table 2). There was no evidence of any vegetation regrowth during this study. Until further research is performed, caution should be exercised when an increase in water resources is used to justify riparian vegetation restoration.

\section{Conclusions}

[45] In riparian corridors, groundwater hydrographs are useful in assessing the role that vegetation plays in local and regional water budgets. In this study, we have explored the use of diurnal groundwater fluctuations as a tool to measure riparian groundwater evapotranspiration and the impacts of understory vegetation removal. To estimate groundwater $E T$, we applied the White method using a range of specific yields based on soil texture properties. We compared groundwater hydrograph estimates of $E T_{g}$ with ET measurements from the 3-D sonic eddy covariance (3SEC) method over a 7-year period at four sites in the Río Grande riparian corridor. In general, groundwater $E T_{g}$ estimates tend to exceed $E T$. The accuracy of riparian $E T_{g}$ values improved as compared with ET when the water table deepened and was decoupled from rapid hydrologic changes in the river channel. The SEV site, which exhibited these conditions, had $E T_{g}$ values that were $0.91-1.65$ times the values of tower $E T$. The differences between $E T_{g}$ and $E T$ increased at riparian sites with shallow water tables that are tightly coupled to changes in the river stage. While the White method appears to work better in certain riparian areas, $E T_{g}$ estimates are sensitive to the vertical heterogeneity of alluvial sediments and its interaction with a fluctuating water table. Using the average textural sizes and the corresponding ranges of readily available specific yield, as we did in this study, might not be appropriate at sites where the water table fluctuates between heterogeneous sediment layers. The best correspondence between $E T_{g}$ and $E T$ values 
occurred at the SEV site where the vertical soil heterogeneity was relatively lower compared with other sites. Thus application of the White method in riparian corridors can be limited by sediment layer composition and heterogeneity, depth to water table, and the degree of hydrological connectivity between the shallow aquifer and the nearby perennial river.

[46] Groundwater hydrographs also can serve as an important indicator of vegetation dynamics within riparian corridors. Vegetation-induced diurnal changes in groundwater fluctuations can be used to gauge patterns of vegetation growth and removal including changes in density, age structure, or species composition. Diurnal groundwater fluctuations should be complemented with measurements of vegetation characteristics, such as LAI and stand density. In this study, we used 3 years of diurnal groundwater fluctuations before and after the removal of understory vegetation. We observed a small but significant reduction in the diurnal groundwater amplitude ranging from 0.32 to $0.86 \mathrm{~cm}(6.7-18.1 \%$ reduction). Since groundwater amplitude captured the effect of understory vegetation removal, this simpler technique has potential field applications that could be further explored, particularly for studies seeking to quantify water salvage due to restoration activities.

[47] Acknowledgments. The National Science Foundation (IGERT Freshwater Sciences Interdisciplinary Doctoral Program, DGE 9972810) provided support for M.C.M. We also would like to acknowledge funding from the Sevilleta Long Term Ecological Research (LTER) program and the National Science Foundation-EPSCoR Research Infrastructue Improvement award. This research also has been funded by NASA award NAG5-6999, the New Mexico Interstate Stream Commission, the U.S. Fish and Wildlife Service's Bosque Initiative, and the U.S. Bureau of Reclamation's Endangered Species Workgroup. This manuscript is Sevilleta LTER publication 455. Special thanks to A. Paz and J. E. Allred Coonrod for providing some of the LAI measurements, and to D. Rankin for helping with gathering the Rio Grande discharge data from USGS. We appreciate the excellent comments from Stephen P. Loheide II, two anonymous reviewers, and an associate editor which helped improve our original manuscript.

\section{References}

Bernhardt, E. S., et al. (2005), Synthesizing U.S. river restoration efforts, Science, 308, 636-637, doi:10.1126/science.1109769.

Biggs, T. W., T. Dunne, and L. A. Martinelli (2004), Natural controls and human impacts on stream nutrient concentrations in a deforested region of the Brazilian Amazon basin, Biogeochemistry, 68, 227-257, doi:10.1023/B:BIOG.0000025744.78309.2e

Birkeland, P. W. (1984), Soils and Geomorphology, Oxford Univ. Press, New York.

Brunke, M., and T. Gonser (1997), The ecological significance of exchange processes between rivers and groundwater, Freshwater Biol., 37, 1-33, doi:10.1046/j.1365-2427.1997.00143.x.

Burt, T. P., et al. (2002), Water table fluctuations in the riparian zone: Comparative results from a pan-European experiment, J. Hydrol., 265, 129-148, doi:10.1016/S0022-1694(02)00102-6.

Butler, J. J., Jr., G. J. Kluitenberg, D. O. Whittemoore, S. P. Loheide II, W. Jin, M. A. Billinger, and X. Zhan (2007), A field investigation of phreatophyteinduced fluctuations in the water table, Water Resour. Res., 43, W02404, doi:10.1029/2005WR004627.

Butturini, A., S. Bernal, E. Nin, C. Hellin, L. Rivero, S. Sabater, and F. Sabater (2003), Influences of the stream groundwater hydrology on nitrate concentration in unsaturated riparian area bounded by an intermittent Mediterranean stream, Water Resour. Res., 39(4), 1110, doi:10.1029/ 2001 WR001260.

Clément, J. C., L. Aquilina, O. Bour, K. Plaine, T. P. Burt, and G. Pinay (2003), Hydrological flowpaths and nitrate removal rates within a riparian floodplain along a fourth-order stream in Brittany (France), Hydrol. Processes, 17, 1177-1195, doi:10.1002/hyp.1192.

Cleverly, J. R., C. N. Dahm, J. R. Thibault, D. J. Gilroy, and J. E. A. Coonrod (2002), Seasonal estimates of actual evapotranspiration from
Tamarix ramosissima stands using three-dimensional eddy covariance, J. Arid Environ., 52, 181-197, doi:10.1006/jare.2002.0972.

Cleverly, J. R., C. N. Dahm, J. R. Thibault, D. E. McDonnell, and J. E. A. Coonrod (2006a), Riparian ecohydrology: Regulation of water flux from the ground to the atmosphere in the Middle Rio Grande, New Mexico, Hydrol. Processes, 20, 3207-3225, doi:10.1002/hyp.6328.

Cleverly, J. R., C. N. Dahm, J. R. Thibault, D. E. McDonnell, and J. E. A. Coonrod (2006b), Groundwater, vegetation, and atmosphere: Comparative riparian evapotranspiration, restoration, and water salvage, in Monitoring Science and Technology Symposium: Unifying Knowledge for Sustainability in the Western Hemisphere, Proc. RMRS-P-42CD, edited by C. Aguirre-Bravo et al., pp. 75-80, For. Serv., U.S. Dep. of Agric., Denver, Colo.

Cooper, D. J., D. R. D’Amico, and M. L. Scott (2003), Physiological and morphological response patterns of Populus deltoides to alluvial groundwater pumping, Environ. Manage. N. Y., 31, 215-226, doi:10.1007/ s00267-002-2808-2.

Cooper, D. J., J. S. Sanderson, D. I. Stannard, and D. P. Groeneveld (2006), Effects of long-term water table drawdown on evapotranspiration and vegetation in an arid region phreatophyte community, J. Hydrol., 325, 21-34, doi:10.1016/j.jhydrol.2005.09.035.

Corell, S. W., F. Corkhill, D. Lovvik, and F. Putman (1996), A groundwater flow model of the Sierra Vista subwatershed of the Upper San Pedro Basin-southeastern Arizona, in Modeling Report Number 10, Hydrol. Div., Dep. of Water Resour., Phoenix, Ariz.

Crawford, C. S., L. M. Ellis, and M. C. Molles (1996), The middle Rio Grande Bosque: An endangered ecosystem, N. M. J. Sci., 36, 276-299. Culler, R. C., R. L. Hanson, R. M. Myrick, R. M. Turner, and F. P. Kipple (1982), Evapotranspiration before and after clearing phreatophytes, Gila River floodplain, Graham County, Arizona, U.S. Geol. Surv. Prof. Pap., $655-P, 655 \mathrm{pp}$.

Dahm, C. N., J. R. Cleverly, J. E. A. Coonrod, J. R. Thibault, D. E. McDonnell, and D. J. Gilroy (2002), Evapotranspiration at the land/water interface in a semi-arid drainage basin, Freshwater Biol., 47, 831-843, doi:10.1046/j.1365-2427.2002.00917.x.

Davis, J. H., S. M. Griffith, W. R. Horwath, J. J. Steiner, and D. D. Myrold (2007), Mitigation of shallow groundwater nitrate in a poorly drained riparian area and adjacent cropland, J. Environ. Qual., 36, 628-637, doi:10.2134/jeq2006.0186.

Dhondt, K., P. Boeckx, N. E. C. Verhoest, G. Hofman, and O. Van Cleemput (2006), Assessment of temporal and spatial variation of nitrate removal in riparian zones, Environ. Monit. Assess., 116, 197-215, doi:10.1007/ s10661-006-7403-1.

Drexler, J. Z., R. L. Snyder, D. Spano, and K. T. Paw (2004), A review of models and micrometeorological methods used to estimate wetland evapotranspiration, Hydrol. Processes, 18, 2071-2102.

Ellis, S. R., G. W. Levings, L. F. Carter, S. F. Richey, and M. J. Radell (1993), Rio Grande valley, Colorado, New Mexico, and Texas, Water Resour. Bull., 29, 617-646.

Farrington, P., G. D. Watson, G. A. Bartle, and E. A. N. Greenwood (1990), Evaporation from dampland vegetation on a groundwater mound, J. Hydrol., 115, 65-75, doi:10.1016/0022-1694(90)90198-7.

Ferretti, D. F., E. Pendall, J. A. Morgan, J. A. Nelson, D. LeCain, and A. R. Mosier (2003), Partitioning evapotranspiration fluxes from a Colorado grassland using stable isotopes: Seasonal variations and ecosystem implications of elevated atmospheric $\mathrm{CO}_{2}$, Plant Soil, 254, 291-303, doi:10.1023/A:1025511618571.

Ferris, J. G. (1951), Cyclic fluctuation of water level as a basis for determining aquifer transmissibility, IAHS Publ., 33, 148-155.

Gerla, P. J. (1992), The relationship of water-table changes to the capillary fringe, evapotranspiration, and precipitation in intermittent wetlands, Wetlands, 12, 91-98.

Goodrich, D. C., et al. (2000), Seasonal estimates of riparian evapotranspiration using remote and in-situ measurements, Agric. For. Meteorol., 105, $281-$ 309, doi:10.1016/S0168-1923(00)00197-0.

Gribovszki, Z., P. Kalicz, J. Szilágyi, and M. Kucsara (2008), Riparian zone evapotranspiration estimation from diurnal groundwater table fluctuations, J. Hydrol., 349, 6-17, doi:10.1016/j.jhydrol.2007.10.049.

Gutiérrez-Jurado, H. A., E. R. Vivoni, E. Istanbulluoglu, and R. L. Bras (2007), Ecohydrological response to a geomorphically significant flood event in a semiarid catchment with contrasting ecosystems, Geophys. Res. Lett., 34, L24S25, doi:10.1029/2007GL030994.

Healy, R. W., and P. G. Cook (2002), Using groundwater levels to estimate recharge, Hydrogeol. J., 10, 91-109, doi:10.1007/s10040-001-0178-0.

Hedin, L. O., J. C. von Fischer, N. E. Ostrom, B. P. Kennedy, M. G. Brown, and G. P. Robertson (1998), Thermodynamic constraints on nitrogen 
transformations and other biogeochemical processes at soil-stream interfaces, Ecology, 79, 684-703.

Hefting, M., J. C. Clement, D. Dowrick, A. C. Cosandey, S. Bernal, C. Cimpian, A. Tatur, T. P. Burt, and G. Pinay (2004), Water table elevation controls on soil nitrogen cycling in riparian wetlands along a European climatic gradient, Biogeochemistry, 67, 113-134, doi:10.1023/ B:BIOG.0000015320.69868.33.

Hornberger, G. M., J. P. Raffensperger, P. L. Wiberg, and K. N. Eshleman (1998), Elements of Physical Hydrology, 302 pp., Johns Hopkins Univ. Press, Baltimore, Md.

Jha, M. K., K. Jayalekshmi, D. Machiwal, Y. Kamii, and K. Chikamori (2004), Determination of hydraulic parameters of an unconfined alluvial aquifer by the floodwave-response technique, Hydrogeol. J., 12, 628642, doi:10.1007/s10040-004-0376-7.

Jung, M., T. P. Burt, and P. D. Bates (2004), Toward a conceptual model of floodplain water table response, Water Resour. Res., 40, W12409, doi:10.1029/2003WR002619.

Lauenroth, W. K., and J. B. Bradford (2006), Ecohydrology and the partitioning of AET between transpiration and evaporation in a semiarid steppe, Ecosystems, 9, 756-767, doi:10.1007/s10021-006-0063-8.

Lautz, L. K. (2008), Estimating groundwater evapotranpiration rates using diurnal water-table fluctuations in a semi-arid riparian zone, Hydrogeol. J., 16, 483-497, doi:10.1007/s10040-007-0239-0.

Leenhouts, J. M. (2005), Hydrology of the San Pedro Riparian National Conservation Area, in Hydrologic Requirements of and Consumptive Ground-Water Use by Riparian Vegetation Along the San Pedro River, Arizona, edited by J. M. Leenhouts, J. C. Stromberg, and R. L. Scott, U.S. Geol. Surv. Sci. Invest. Rep., 2005-5163, 23-55.

Leyer, I. (2005), Predicting plant species' responses to river regulation: The role of water level fluctuations, J. Appl. Ecol., 42, 239-250, doi:10.1111/ j.1365-2664.2005.01009.x.

Loheide, S. P., II (2008), A method for estimating subdaily evapotranspiration of shallow groundwater using diurnal water table fluctuations, Ecohydrology, 1, 59-66.

Loheide, S. P., II, J. J. Butler Jr., and S. M. Gorelick (2005), Use of diurnal water table fluctuations to estimate groundwater consumption by phreatophytes: A saturated-unsaturated flow assessment, Water Resour. Res., 41, W07030, doi:10.1029/2005WR003942.

Lowrance, R., et al. (1997), Water quality functions of riparian forest buffers in Chesapeake Bay watersheds, Environ. Manage. N. Y., 21, 687-712, doi:10.1007/s002679900060.

Matheussen, B., R. L. Kirschbaum, I. A. Goodman, G. M. O’Donnell, and D. P. Lettenmaier (2000), Effects of land cover change on streamflow in the interior Columbia River Basin (USA and Canada), Hydrol. Processes, 14, 867-885, doi:10.1002/(SICI)1099-1085(20000415)14:5< 867::AID-HYP975>3.0.CO;2-5.

Meyboom, P. (1964), Three observations on streamflow depletion by phreatophytes, J. Hydrol., 2, 248-261, doi:10.1016/0022-1694(65)90040-5.

Milne, B. T., D. I. Moore, J. L. Betancourt, J. A. Parks, T. W. Swetnam, R. R. Parmenter, and W. T. Pockman (2003), Multidecadal drought cycles in southcentral New Mexico: Patterns and consequences, in Climate Variability and Ecosystem Responses at Long-Term Ecological Research Sites, edited by D. Greenland, D. G. Goodin, and R. C. Smith, pp. 286-307, Oxford Univ. Press, New York.

Molles, M. C., C. S. Crawford, L. M. Ellis, H. M. Valett, and C. N. Dahm (1998), Managed flooding for riparian ecosystem restoration: Managed flooding reorganizes riparian forest ecosystems along the middle Rio Grande in New Mexico, BioScience, 48, 749-756, doi:10.2307/ 1313337.

Morrice, J. A., H. M. Valett, C. N. Dahm, and M. E. Campana (1997), Alluvial characteristics, groundwater-surface water exchange and hydrological retention in headwater streams, Hydrol. Processes, 11, 253-267, doi:10.1002/(SICI)1099-1085(19970315)11:3<253::AID-HYP439> 3.0.CO;2-J

Nagler, P. L., R. L. Scott, C. Westenburg, J. R. Cleverly, E. P. Glenn, and A. R. Huete (2005), Evapotranspiration on western US rivers estimated using the Enhanced Vegetation Index from MODIS and data from eddy covariance and Bowen ratio flux towers, Remote Sens. Environ., 97, 337-351, doi:10.1016/j.rse.2005.05.011.

Neill, C., L. A. Deegan, S. M. Thomas, C. L. Haupert, A. V. Krusche, V. M. Ballester, and R. L. Victoria (2006), Deforestation alters the hydraulic and biogeochemical characteristics of small lowland Amazonian streams, Hydrol. Processes, 20, 2563-2580, doi:10.1002/hyp.6216.

Newman, B. D., B. P. Wilcox Sr., D. D. Archer, C. N. Breshears, C. J. Dahm, N. G. Duffy, F. M. McDowell, B. R. Phillips, B. R. Scanlon, and E. R. Vivoni (2006), Ecohydrology of water-limited environments: A scientific vision, Water Resour. Res., 42, W06302, doi:10.1029/ 2005WR004141.

Palmer, M. A., et al. (2005), Standards for ecologically successful river restoration, J. Appl. Ecol., 42, 208-217, doi:10.1111/j.1365-2664. 2005.01004.x.

Parker, D. L., M. Renz, A. Fletcher, F. Miller, and J. Gosz (2005), Strategy for long-term management of exotic trees in riparian areas for New Mexico's five river systems, 2005-2014, report, 24 pp., U.S. Dep. of Agric., Washington, D. C.

Peterjohn, W. T., and D. L. Correll (1984), Nutrient dynamics in an agricultural watershed: Observations on the role of a riparian forest, Ecology, 65, 1466-1475, doi:10.2307/1939127.

Qashu, H. K., and D. D. Evans (1967), Water disposition in a stream channel with riparian vegetation, Soil Sci. Soc. Am. Proc., 31, 263-269.

Rodríguez-Iturbe, I., P. D'Odorico, F. Laio, L. Ridolfi, and S. Tamea (2007), Challenges in humid land ecohydrology: Interactions of water table and unsaturated zone with climate, soil, and vegetation, Water Resour. Res., 43, W09301, doi:10.1029/2007WR006073.

Rosenberry, D. O., and T. C. Winter (1997), Dynamics of water-table fluctuations in an upland between two prairie-pothole wetlands in North Dakota, J. Hydrol., 191, 266-289, doi:10.1016/S0022-1694(96)03050-8.

Schilling, K. E., Y. K. Zhang, and P. Drobney (2004), Water table fluctuations near an incised stream, Walnut Creek, Iowa, J. Hydrol. Amsterdam, 286, 236-248, doi:10.1016/j.jhydrol.2003.09.017.

Schilling, K. E., Z. W. Li, and Y. K. Zhang (2006), Groundwater-surface water interaction in the riparian zone of an incised channel, Walnut Creek, Iowa, J. Hydrol., 327, 140-150, doi:10.1016/j.jhydrol.2005. 11.014 .

Scott, R. L., D. G. Williams, D. C. Goodrich, W. L. Cable, L. R. Levick, R. McGuire, R. M. Gazal, E. A. Yepez, P. Ellsworth, and T. E. Huxman (2005), Determining the riparian ground-water use within the San Pedro riparian national conservation area and the Sierra Vista subwatershed, in Hydrologic Requirements of and Consumptive Ground-Water Use by Riparian Vegetation Along the San Pedro River, Arizona, edited by J. M. Leenhouts, J. C. Stromberg, and R. L. Scott, U.S. Geol. Surv. Sci. Invest. Rep., 2005-5163, 107-153.

Shafroth, P. B., J. R. Cleverly, T. L. Dudley, J. P. Taylor, C. Van Riper, E. P. Weeks, and J. N. Stuart (2005), Control of Tamarix in the western United States: Implications for water salvage, wildlife use, and riparian restoration, Environ. Manage. N. Y., 35, 231-246, doi:10.1007/s00267-0040099-5.

Shah, J. J. F., C. N. Dahm, S. P. Gloss, and E. S. Bernhardt (2007), River and riparian restoration in the southwest: Results of the national river restoration science synthesis project, Restoration Ecol., 15, 550-562, doi:10.1111/j.1526-100X.2007.00250.x.

Sjodin, A., W. M. Lewis, and J. F. Saunders (2001), Analysis of groundwater exchange for a large plains river in Colorado (USA), Hydrol. Processes, 15, 609-620, doi:10.1002/hyp.173.

Smith, A. J. (1999), Application of a tidal method for estimating aquifer diffusivity: Swan River, Western Australia, CSIRO Rep. 13/99, 15 pp., Commonwealth Sci. and Ind. Res. Organ., Sydney, N. S. W., Australia.

Smith, R. L., B. L. Howes, and J. H. Duff (1991), Denitrification in nitratecontaminated groundwater: Occurrence in steep vertical geochemical gradients, Geochim. Cosmochim. Acta, 55, 1815-1825, doi:10.1016/ 0016-7037(91)90026-2.

Stednick, J. D. (1996), Monitoring the effects of timber harvest on annual water yield, J. Hydrol., 176, 79-95, doi:10.1016/0022-1694(95)02780-7.

Steinwand, A. L., R. F. Harrington, and D. Or (2006), Water balance for Great Basin phreatophytes derived from eddy covariance, soil water, and water table measurements, J. Hydrol., 329, 595-605, doi:10.1016/ j.jhydrol.2006.03.013

Swank, W. T., J. M. Vose, and K. J. Elliott (2001), Long-term hydrologic and water quality responses following commercial clearcutting of mixed hardwoods on a southern Appalachian catchment, For. Ecol. Manage., 143, 163-178, doi:10.1016/S0378-1127(00)00515-6.

Tabacchi, E., L. Lambs, H. Guilloy, A. M. Planty-Tabacchi, E. Muller, and H. Decamps (2000), Impacts of riparian vegetation on hydrological processes, Hydrol. Processes, 14, 2959-2976, doi:10.1002/10991085(200011/12)14:16/17<2959::AID-HYP129>3.0.CO;2-B.

Thorburn, P. J., T. J. Hatton, and G. R. Walker (1993), Combining measurements of transpiration and stable isotopes of water to determine groundwater discharge from forests, J. Hydrol., 150, 563-587, doi:10.1016/ 0022-1694(93)90126-T.

Troxell, H. C. (1936), The diurnal fluctuation in the ground-water and flow of the Santa Ana river and its meaning, Eos Trans. AGU, 17, 469-504.

Vellidis, G., R. Lowrance, P. Gay, and R. K. Hubbard (2003), Nutrient transport in a restored riparian wetland, J. Environ. Qual., 32, 711-726. 
Vivoni, E. R., R. S. Bowman, R. L. Wyckoff, R. T. Jakubowski, and K. E. Richards (2006), Analysis of a monsoon flood event in an ephemeral tributary and its downstream hydrologic effects, Water Resour. Res., 42, W03404, doi:10.1029/2005WR004036.

Weiss, J. L., D. S. Gutzler, J. E. A. Coonrod, and C. N. Dahm (2004), Seasonal and inter-annual relationships between vegetation and climate in central New Mexico, USA, J. Arid Environ., 57, 507-534, doi:10.1016/S0140-1963(03)00113-7.

Welder, G. E. (1988), Hydrologic effects of phreatophyte control, AcmeArtesia reach of the Pecos river, New Mexico, 1967-82, U.S. Geol. Surv. Water Resour. Invest. Rep., 87-4148, 46 pp.

White, W. N. (1932), A method of estimating ground-water supplies based on discharge by plants and evaporation from soil: Results of investigations in Escalante Valley, Utah, U.S. Geol. Surv. Water Supply Pap., 659-A, 105 pp.

Wigington, P. J., S. M. Griffith, J. A. Field, J. E. Baham, W. R. Horwath, J. Owen, J. H. Davis, S. C. Rain, and J. J. Steiner (2003), Nitrate removal effectiveness of a riparian buffer along a small agricultural stream in Western Oregon, J. Environ. Qual., 32, 162-170.

Wilcox, B. P., and T. L. Thurow (2006), Emerging issues in rangeland ecohydrology: Vegetation change and the water cycle, Rangeland Ecol. Manage., 59, 220-224, doi:10.2111/05-090R1.1.

Wilcox, B. P., M. K. Owens, W. A. Dugas, D. N. Ueckert, and C. R. Hart (2006), Shrubs, streamflow, and the paradox of scale, Hydrol. Processes, 20, 3245-3259, doi:10.1002/hyp.6330.

Wissmar, R. C. (2004), Riparian corridors of eastern Oregon and Washington: Functions and sustainability along lowland-arid to mountain gradients, Aquat. Sci., 66, 373-387, doi:10.1007/s00027-004-0720-y.
Woessner, W. W. (2000), Stream and fluvial plain ground water interactions: Rescaling hydrogeologic thought, Ground Water, 38, 423-429, doi:10.1111/j.1745-6584.2000.tb00228.x.

Wohl, E., P. L. Angermeier, B. Bledsoe, G. M. Kondolf, L. MacDonnell, D. M. Merritt, M. A. Palmer, N. L. Poff, and D. Tarboton (2005), River restoration, Water Resour. Res., 41, W10301, doi:10.1029/ 2005WR003985.

Yepez, E. A., D. G. Williams, R. L. Scott, and G. Lin (2003), Partitioning overstory and understory evapotranpiration in a semiarid savanna woodland from the isotopic composition of water vapor, Agric. For. Meteorol., 119, 43-68, doi:10.1016/S0168-1923(03)00116-3.

Zhang, Y. K., and K. E. Schilling (2006), Effects of land cover on water table, soil moisture, evapotranspiration, and groundwater recharge: A field observation and analysis, J. Hydrol., 319, 328-338, doi:10.1016/ j.jhydrol.2005.06.044.

J. R. Cleverly, C. N. Dahm, M. C. Martinet, J. F. Schuetz, and J. R. Thibault, Department of Biology, University of New Mexico, 167 Castetter Hall, MSC03 2020, 1 University Avenue, Albuquerque, NM 87131-0001, USA. (conuco8@unm.edu)

E. Vivoni, Department of Earth and Environmental Science, New Mexico Institute of Mining and Technology, 801 Leroy Place, Socorro, NM 87801, USA. 